\title{
MODELLING OF CRYSTAL STRUCTURE OF CIS-1,2,3,6 AND 3,4,5,6- TETRAHYDROPHTALIC ANHYDRIDES USING LATTICE ENERGY CALCULATIONS
}

\author{
A. Ben Fredj ${ }^{a}$ and G. M. Day ${ }^{b}$ \\ ${ }^{a}$ Laboratoire de Spectroscopie Atomique, Moléculaire et Applications, Faculté des Sciences \\ de Tunis, Campus Universitaire 1060, Tunis, Tunisie. (e-mail : erijbf@ yahoo.fr) \\ ${ }^{\mathrm{b}}$ Chemistry, University of Southampton, Southampton, SO17 1BJ. \\ (e-mail: G.M.Day@ soton.ac.uk)
}

\begin{abstract}
Lattice energy calculations using a model potential have been performed to model the crystal structures of cis-1,2,3,6- and 3,4,5,6-tetrahydrophthalic anhydrides. The optimized molecular models using the DFT method at the B3LYP/6-31G** level were found consistent with the available experimental evidence and allow to reproduce all differences observed in crystal packing between cis-1,2,3,6- and 3,4,5,6-tetrahydrophthalic anhydrides. Calculations provide evidence for the presence of dipole-dipole $\mathrm{C}=\mathrm{O} \ldots \mathrm{C}=\mathrm{O}$ intermolecular interactions and support the idea that the molecules distort from their ideal geometries, improving packing in both crystals. The search for minima in the lattice energy of both crystals amongst the more common space groups with $Z^{\prime}=1$, using a simulated annealing crystal structure prediction procedure followed by lattice energy minimisation shows that the observed structure of 3,4,5,6-tetrahydrophthalic anhydride $\left(Z^{\prime}=2\right)$ is the thermodynamically most stable and allow us to justify why 3,4,5,6-tetrahydropthalic anhydride crystallises in such complex structure with 16 molecules in the unit cell. The computational model was successful to predict the second observed form at $173 \mathrm{~K}$ for cis-1,2,3,6-tetrahydropthalic anhydride as a polymorph and could predict several hypothetical structures with $Z^{\prime}=1$ which appear competitive with the observed structures. The results of phonon estimates of zero point intermolecular vibrational energy and entropy suggest that crystal structures of cis-1,2,3,6-tetrahydropthalic anhydride cannot be predicted just on the basis of lattice energy, there are yet, other factors than thermodynamics favoring the observed structures.
\end{abstract}

Key words Anhydrides, Crystal structure prediction, Lattice energy calculation, Intermolecular interactions. 


\section{Introduction}

Tetrahydrophthalic anhydrides offer very attractive properties as intermediates or starting materials in chemical synthesis because they provide an easy access to other cyclohexene-1,2-dicarboxylic anhydrides and their analogues [1]. In the course of the structure determinations of a series of tetrahydrophthalic anhydride isomers [2-5], we found that the cis-1,2,3,6- and 3,4,5,6-tetrahydrophthalic (THP) anhydrides (Fig.1) adopt unexpectedly complex structures [2,4], that are very different from those of geometrically similar molecules [6-12]. Both isomers crystallise with two independent molecules per asymmetric unit $\left(Z^{\prime}=2\right)$, with $Z=8$ molecules per unit cell in the space group $P 2{ }_{1} /$ a for cis1,2,3,6-THP anhydride [2] and $Z=16$ molecules in the unit cell of $P b c a$ symmetry for 3,4,5,6THP anhydride [4]. Their crystal structures exhibit an interesting columnar packing pattern, sustained by an extensive network of non-bonded intermolecular $\mathrm{C}=\mathrm{O} \ldots \mathrm{C}=\mathrm{O}$ interactions of dipole-dipole type $[3,13]$. Discussion of these intermolecular interactions in terms of typical geometrical criteria [14] allows us to argue that there is an obvious relationship between these specific intermolecular interactions and the packing modes of these crystal isomers.

The cis-1,2,3,6-THP anhydride isomer (Form I) showed polymorphism: M. Bolte et al. [15] crystallised it from a solution in ether at $173 \mathrm{~K}$ and found an orthorhombic structure with $\mathrm{Z}=8$ in space group $P c a 2_{1}$. This new form II (space group: Pca2 $2_{1} ; Z^{\prime}=2$ ) was shown to have approximately the same packing motif with two nearly identical molecules as the monoclinic polymorph (Form I). A facile transformation to the orthorhombic is likely, as six of the eight molecules in the unit cell occupy almost exactly the same positions, whereas the remaining two are mutually related by a non-crystallographic mirror plane [15]. It is important to note that this structure was determined in connection with a study of the possible chemical decomposition of the compound in different solvents and in contact with atmosphere. The authors reported that no decomposition could be observed during the time of examination.

Thus the complex crystal structures of cis-1,2,3,6- and 3,4,5,6-THP anhydrides require explanation. Why both molecules crystallise with $Z^{\prime}>1$ ? Are the $Z$ ' $=2$ crystal packings the most thermodynamically stable for cis-1,2,3,6- and 3,4,5,6-THP anhydrides? Is there an energetic driving factor in the formation of a bimolecular asymmetric unit? Are these crystal packing the results of specific directional intermolecular interactions which may implicate an increasing in Z' (by causing the break-down of the molecular symmetry and which cannot be described by a space group symmetry operation)?

The review of crystal materials, where X-ray diffraction detects more than one molecule in the asymmetric unit $\left(Z^{\prime}>1\right)$ indicates that these structure types were very common for organic compounds. In literature, many crystal chemists have investigated the origins of the phenomenon of the presence of multiple molecules in the crystallographic asymmetric unit $\left(Z^{\prime}>1\right)$ using a large database of organic crystalline solids [16-20]. Some interesting aspects of crystal packing emerge, and answers are given for specific cases and proposed in general. However, conclusions were somewhat elusive because broad ranges of structure types and energetic behaviour appear.

In this work, we have tried to give an answer to the questions for the specific cases of crystal structures of cis-1,2,3,6- and 3,4,5,6-tetrahydrophthalic anhydrides using lattice energy calculations. A suitable set of hypothetical crystal structures can be generated by searching for minima in the lattice energy, using methods developed for crystal structure prediction [21]. These methods were shown to be successful at finding the experimental observed crystal structures of small rigid organic molecules at, or close to, the global minimum in the lattice energy [22], even in blind tests [23], although the searches are often restricted to the most common packing types: generally $Z^{\prime}=1$ in the highest populated space groups in the Cambridge Structural Database. Hence, a comparison between the energies of the 
hypothetical Z' $=1$ and the experimentally observed $\left(Z^{\prime}=2\right)$ crystal structures should reveal the thermodynamically most favourable packing for the anhydride compounds and can provide valuable information on which factors favours the observed structures. The calculated models are discussed and compared with the available experimental data of both isomers.

\section{Computational methods}

Lattice energy calculations using a model potential that describes pairwise intermolecular (repulsion, dispersion and electrostatic) contributions to the lattice energy were applied in the modelling of the crystal structures of cis-1,2,3,6- and 3,4,5,6-tetrahydrophthalic anhydrides. Two molecular models were used in the optimisation procedure for each known crystal structure. For the first model of calculation ("HOpt" model), the molecular geometries were taken from the experimentally determined crystal structures, except that the positions of hydrogen atoms were corrected using isolated molecule density functional theory (DFT) calculations; the positions of all heavy atoms were constrained, while hydrogen atom positions were relaxed. The second models used for lattice energy calculations ("FullOpt" model) employed idealised molecular models from full optimisation of the isolated molecules using DFT. The CADPAC program [24] was employed for all the DFT calculations and the B3LYP/6-31G** level of theory was used throughout. The electrostatic model for intermolecular interactions was derived from the DFT charge density, obtaining atomic multipoles (charge, dipole, quadrupole, octopole and hexadecapole on each atom) using the distributed multipole analysis [25, 26]. Charge-charge and charge-dipole interactions were summed by Ewald summation, while all higher interactions (up to $\mathrm{R}^{-5}$ ) were summed to a $15 \AA$ cutoff between whole molecules. The rest of the model for intermolecular interactions was taken from Williams' empirically derived set of parameters for an exponential-6 repulsiondispersion model potential $[27,28]$. These were summed to a $15 \AA$ direct-space cutoff. This combination of empirical exp-6 repulsion-dispersion potentials with a distributed multipole electrostatic model has been successfully used for modelling the crystal structures of a wide range of polar organic compounds [29].

The experimentally determined crystal structures of both molecules were lattice energy minimised with the two molecular models (HOpt and FullOpt) to find the nearest potential energy minimum to the observed structures, using the crystal structure modelling program DMAREL [30]. Hypothetical structures with one molecule per asymmetric unit $\left(Z^{\prime}=1\right)$ for both anhydride compounds were generated using the Monte Carlo simulated annealing method, as implemented in the Polymorph Predictor module of the Cerius2 package [31]. Multiple searches were performed in the nine most common space groups $\left(P 2_{1} / c, P-1\right.$, $\left.P 2{ }_{1} 22_{1}, P 2_{1}, C 2 / c, P b c a, P n a 2_{1}, P c a 2_{1}, P b c n\right)$, until no new structures were generated; this required four independent simulated annealing runs in each space group for each molecule. These hypothetical crystal structures were generated using the fully optimised molecular geometries (FullOpt). The lowest energy structures from the simulated annealing searches were then used as starting points for lattice energy minimisation in DMAREL using the DMA-based model potential and the methodology described above. For a fair comparison between the energies of the hypothetical and experimental structures, exactly the same molecular model and intermolecular potential was used. The eigenvalues of the second derivatives matrix were examined for all (minimised experimental and computer-generated hypothetical) crystal structures to ensure that true minima were found. The second derivative matrix at the minimum was used to calculate the corresponding the $\mathbf{k}=0$ phonons. The set of the phonon frequencies were used to estimate the intermolecular contribution to the zero point and thermal free energy of the crystal using a hybrid Debye-Einstein model of phonon dispersion [32]. 


\section{Results of theoretical calculations and comparison with experiment}

\section{-Cis-1,2,3,6-tetrahydrophthalic anhydride}

Lattice energy calculations using either the experimentally observed molecular geometry or the idealised (fully optimised) molecular structure give excellent agreement with the experimentally determined crystal structures. The optimised unit cell parameters are very close to the experimentally observed values (Fig. 2); deviations are $0.20 \AA$ for $\mathrm{a}, 0.03 \AA$ for $\mathrm{b}$ and 0.06 for $\mathrm{c}$ with the "Hopt" model and of $0.09 \AA$ for a, $0.06 \AA$ for $\mathrm{b}$ and $0.14 \AA$ for $\mathrm{c}$ with the "FullOpt" model (Table 1). The unique angle $\beta$ remained virtually unaltered during lattice energy minimisation using both the HOpt and FullOpt models. The difference is less than one standard deviation for all cell parameters and thus the agreement between the theoretical and the experimental geometries is excellent. The ability of the model potential to reproduce the experimental crystal structure of cis-1,2,3,6-THP is shown in Table 2. Comparing the experimental geometrical parameters with those from the DFT optimisation, we note the following upon inspection. The maximum discrepancy in the bond distances is of $0.04 \AA$ at $\mathrm{C}=\mathrm{C}$ double bond and the largest differences in the valence and torsion angles are $2.6^{\circ}$ and $5.5^{\circ}$ for $\mathrm{O}=\mathrm{C}-\mathrm{O}$ and $\mathrm{C}=\mathrm{C}-\mathrm{C}-\mathrm{C}$ respectively. While these differences are small, they do influence the molecular packing and it follows that the model which uses the observed molecular structure (HOpt) gives slightly better agreement with the experimental crystal structure. Furthermore, the distortion from ideal molecular geometry allows an improved

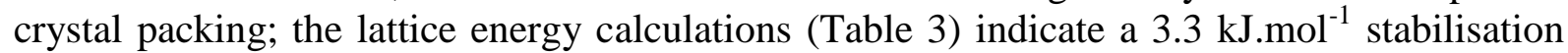
(HOpt - FullOpt). The lattice energy calculations support the idea that the molecule distorts slightly from its ideal geometry and improves the packing of the crystal structure of cis1,2,3,6-tetrahydrophthalic anhydride.

Interestingly, the short intermolecular distances observed between nucleophilic oxygen atoms and electrophilic carbons bonded to the oxygen atoms (Fig.3) are reproduced in both sets of calculation (Table 4). The tabulated intermolecular distances reproduce the observed values with a maximum deviation of $0.1 \AA$. The calculated non-covalent bond angles $\theta$ corresponding to the $\mathrm{d}(\mathrm{C}=\mathrm{O} \ldots \mathrm{C}=\mathrm{O})$ abstraction distance deviate no more than $2.5^{\circ}$ from those we have determined experimentally by X-ray diffraction technique and are in quite agreement with earlier conclusions from ab initio calculations, whatever the nucleophilic reagent $(\mathrm{O} \ldots \mathrm{C}=\mathrm{O})$, its optimal approach occurs towards the $\mathrm{C}=\mathrm{O}$ carbon atom with $\theta$ (O...CO) angles generally greater than $90^{\circ}$, and in the range $100-120^{\circ}[33,34]$.

Both models of calculation are in good accord with the experimental results. Moreover it is noticeable that the averaged value of dihedrals angles corresponding to the oxygen and carbon atom $\mathrm{C}=\mathrm{O}$ as nucleophilic and electrophilic reagents which are found respectively in the average equal to $91.4^{\circ}$ (HOpt) and to $91^{\circ}$ (FullOpt) are close the bisecter criterium $\left(\varphi=90^{\circ}\right)[14]$. Results from $>\mathrm{O} \ldots \mathrm{C}=\mathrm{O}$ intermolecular interactions (Table 4) show variation of the shortest $\mathrm{d}(>\mathrm{O} \ldots \mathrm{C}=\mathrm{O})$ values from $3.74 \AA$ to $5.13 \AA$ with an approach angle in the range $\left[44.8^{\circ}-99.9^{\circ}\right]$ (HOpt) and $\left[45.5^{\circ}-96.9^{\circ}\right]$ (FullOpt); in the crystal of cis-1,2,3,6tetrahydrophthalic anhydride, the $\theta$ packing does not depend on $(>\mathrm{O} \ldots \mathrm{C}=\mathrm{O})$ angle and appear to be mainly on the $\theta$ (CO...CO) control [14]. This can be correlated with anhydride crystal data which show an almost random distribution of $\theta(>\mathrm{O} \ldots \mathrm{C}=\mathrm{O})$ from $48.7^{\circ}$ to $96.8^{\circ}$ for $>\mathrm{O} \ldots \mathrm{C}=\mathrm{O}$ intermolecular interactions $[2,13]$. Therefore, these calculations a posteriory justify the presence of $\mathrm{C}=\mathrm{O} \ldots \mathrm{C}=\mathrm{O}$ interactions in crystal of cis-1,2,3,6-tetrahydrophthalic 
anhydride. These typical dipole-dipole $\mathrm{C}=\mathrm{O} \ldots \mathrm{C}=\mathrm{O}$ intermolecular interactions seem to be directly related to the packing modes of cis-1,2,3,6-tetrahydropthalic anhydride.

Moreover, we have found that these strong intermolecular interactions between the carbonyl groups can be at the origin of the deformation of the molecule which can be traduced by a folding about an axis passing in the vicinity of atoms $\mathrm{C}_{3}$ and $\mathrm{C}_{6}$ of the cyclehexene ring (Fig. 3). This was justified by the calculation of the dihedral angles of the mean planes characterising the two rings of the molecule and the deviation of atoms with respect to these planes [13]. These observations have stimulated the conception that this type of interactions dominating the packing energy of cis-1,2,3,6-tetrahydrpthalic anhydride can be considered as a reliable indicator for a structure predisposition toward crystal packing with multiple symmetry formula units. In this example, the strongest $\mathrm{C}=\mathrm{O} \ldots \mathrm{C}=\mathrm{O}$ are found between the largest faces of the anhydride ring of independent molecules implying that molecules are fitting together to minimise the surface area and emphasising the importance of other factors which are the molecular shape and flexibility. The idea of high Z' structures arising as a consequence of awkward molecular shape has been postulated by several authors $[35,36]$. From these studies, molecules crystallizing with $Z^{\prime}>1$ are more awkward than those crystallizing with $Z^{\prime}=1$. Analysis of homomolecular $\left(Z^{\prime}=1\right)$ monocyclic anhydride's structures $[9,10]$ proved that these compounds are less awkward. However, other polycyclic anhydrides adopting similar folded structures $[6-8,11-12,37-43]$ are more likely awkward still. Although all their packing exhibit intermolecular $\mathrm{C}=\mathrm{O} \ldots \mathrm{C}=\mathrm{O}$ interactions, their crystal structures did not exhibit a deformation of the independent molecules and high $Z$ ' structure. This is explained by the fact that their molecules are all characterized by rigid bodies and blocked geometries unlike cis-1,2,3,6-tetrahydrophthalic anhydride. We have also considered, in this study, the question of high Z' structure arising from the possibility of many different possible conformations of a flexible molecule. This hypothesis seem at odds with the observation that both independent molecules in the asymmetric unit have very similar folded conformations. The apparent differences between independent molecules are not over interpreted as being different conformers as in the case of others high Z' structures [44, 45]. The observation of very similar conformations in the structure of cis-1,2,3,6-tetrahydropthalic anhydride (Form I) and its second polymorph (Form II) may be interpreted to mean that differences between formula groups are consequence rather than a cause of high $\mathrm{Z}$ ' behaviour.

Perhaps, the most interesting aspect of this study is the comparison between molecular packing of $Z^{\prime}=1$ and $Z^{\prime}=2$ structures. The search of hypothetical crystal structures with one molecule in the asymmetric unit $\left(Z^{\prime}=1\right)$ in common packing types by lattice energy minimisation is shown in Fig.4. The results reveal that there is a cluster of computedgenerated $Z^{\prime}=1$ crystal structures at about the same energy as the observed structure. There are two minima in the lattice energy of cis-1,2,3,6-tetrahydropthalic anhydride that are lower in lattice energy than the experimentally observed structure and are in space groups $P 2_{1} / a$ and $P 22_{1} 2_{1} 2_{1}$. Their lattice energies are -80.09 and $-80.03 \mathrm{~kJ} / \mathrm{mol}$ respectively, being only about 0.1 $\mathrm{kJ} / \mathrm{mol}$ lower than the experimentally observed structure. The lattice energies, densities, space groups and the cell dimensions of the ten low energy hypothetical structures with $Z^{\prime}=1$ are tabulated in Table 5 (The .Cif files of the ten lowest structures with $Z^{\prime}=1$, are reported as supplementary material). The ten lowest energy hypothetical structures $\left(Z^{\prime}=1\right)$ all have similar density, with some of the most stable being more significantly denser than the experimental observed structure for both I and II forms. The calculated value of the lattice energy of Form II is found equal to $-79.94 \mathrm{~kJ} / \mathrm{mol}$, being very close to that of Form I which is calculated to be $79.97 \mathrm{~kJ} / \mathrm{mol}$. This result also confirm the quality and the transferability of the potential used in reproducing the second observed polymorph of cis-1,2,3,6tetrahydropthalic anhydride. 
The packing is very different in the two predicted $Z^{\prime}=1$ crystal structures that are lower in energy than the observed $Z^{\prime}=2$ structure. In place of nearly perpendicular $C=O \ldots C=O$ contacts, the nearest contact with $\mathrm{C}=\mathrm{O}$ groups in both predicted $Z^{\prime}=1$ crystal structures is from the oxygen in the ring $(\mathrm{O} \ldots \mathrm{C}=\mathrm{O})$, at a distance of $3.00 \AA$ in the monoclinic $\left(P 2_{1} / a\right)$ global minimum predicted structure, and $3.02 \AA$ in the orthorhombic $\left(P 2_{1} 2_{1} 2_{1}\right)$ predicted structure. These contacts occur in T-shape interactions between hetero-rings. The results indicate that this packing leads to denser structures, at the expense of having the replace the most favourable $\mathrm{C}=\mathrm{O} \ldots \mathrm{C}=\mathrm{O}$ interactions by slightly less stabilising $\mathrm{O} \ldots \mathrm{C}=\mathrm{O}$ contacts.

Lattice dynamical contributions have been shown to be important in assessing the relative stabilities of observed and predicted polymorphs [46, 47]. In this case, the harmonic phonon estimates of the zero point intermolecular vibrational energy and entropy did not refine the relative thermodynamic stability (Table 5 ). The two lowest hypothetical structures with $Z{ }^{\prime}=1$ corresponding to $P 2_{1} 2_{1} 2_{1}$ and $P 2_{1} / c$ space groups respectively are the most stable thermodynamically according to the Helmholtz energy at ambient temperature. The predicted variation in the vibrational energy terms between the most stable hypothetical and the experimental observed structures is only of a few $\mathrm{kJ} / \mathrm{mol}$ and thus, calculation, clearly, predict that cis-1,2,3,6-THP anhydride could potentially have several polymorphs.

Although we have endeavoured to use the most realistic electrostatic model and the most reasonable transferability assumptions for the empirical repulsion-dispersion terms, it seems likely that the errors in the relative energies are such that the hypothetical structures are thermodynamically more favourable than the experimental observed ones. Despite these limitations, the low energy structure of Table 5 are deposited so that other ideas for predicting which energetically feasible crystal structures will actually be observed can applied, and possibly help to resolve the question of why the $Z=2$ structures are observed. It is possible that different nucleation conditions, perhaps with seeding or during crystallisation experiments, could produce other polymorphs of cis-1,2,3,6-tetrahydropthalic anhydride. If this happens the low energy crystal structures could help to identify the new polymorphs.

\section{- 3,4,5,6-tetrahydrophthalic anhydride}

The calculations for 3,4,5,6-tetrahydrophthalic anhydride, also reproduce the experimentally observed crystal structure very well; the geometry at the energy minimum is very close to that observed by diffraction technique (Fig. 5). The results for the unit cell, Table 6, and for the individual interatomic distances and angles, Table 7, indicate that both HOpt- and FullOpt- models of calculation reproduce the unit cell dimensions and the internal structure of the unit cell. The experimental observed bond lengths, valence angles and torsion angles (Fig. 6) deviated by at most $0.02 \AA, 1.8^{\circ}$ and $3.0^{\circ}$ from the (FullOpt) fully optimised molecular geometry.

As with cis-1,2,3,6-THP anhydride, the molecular distortion between idealised and observed molecular geometries lowers the calculated lattice energy; here, the observed (HOpt)

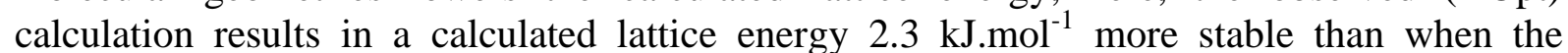
idealised (FullOpt) molecular geometry is used (Table 3). As stated in the case of cis-1,2,3,6THP anhydride, results of the calculations are evidence that the 3,4,5,6-THP anhydride molecule structure is distorted slightly to improve the molecular packing in the crystal structure.

Detailed analysis of the geometrical intermolecular parameters reported in Table 8, shows a large number of close intermolecular contacts among carbonyl groups of neighbouring molecules. The shortest contacts $(3.001 \AA$ and $2.989 \AA)(\mathrm{HOpt})$ and $(2.997 \AA$ and 2.998 $\AA)($ FullOpt) are correctly predicted to be between symmetry related of molecules (I) or (II). 
The calculated values are in excellent agreement with the experimental results (Fig. 7) [4]; the calculated intermolecular atom-atom distances reproduce the observed values with a maximum deviation of $0.06 \AA$ and $0.07 \AA$ respectively using the HOpt and the FullOpt computational models (Table 8). Similarly, the corresponding non covalent $\theta$ angles are adequately reproduced in both models; the maximum discrepancy is $1.5^{\circ}$ at $\mathrm{O}_{5} \ldots \mathrm{C}_{16}=\mathrm{O}_{6}$ and $\mathrm{O}_{3} \ldots \mathrm{C}_{1}=\mathrm{O}_{2}$ (HOpt) and of $4.7^{\circ}$ at $\mathrm{O}_{5} \ldots \mathrm{C}_{16}=\mathrm{O}_{6}$ (FullOpt).

Detailed analysis of the geometrical intermolecular parameters reported in Table 9, shows a large number of close intermolecular contacts among carbonyl groups of neighbouring molecules. The shortest contacts $(3.001 \AA$ and $2.989 \AA)(\mathrm{HOpt})$ and $(2.997 \AA$ and 2.998 $\AA)($ FullOpt) are correctly predicted to be between symmetry related of molecules (I) or (II). The calculated values are in excellent agreement with the experimental results (Table 10); the calculated intermolecular atom-atom distances reproduce the observed values with a maximum deviation of $0.06 \AA$ and $0.07 \AA$ respectively using the HOpt and the FullOpt computational models (Table 9). Similarly, the corresponding non covalent $\theta$ angles are adequately reproduced in both models; the maximum discrepancy is $1.5^{\circ}$ at $\mathrm{O}(5) \ldots \mathrm{C}(16)=\mathrm{O}(6)$ and $\mathrm{O}(3) \ldots \mathrm{C}(1)=\mathrm{O}(2)(\mathrm{HOpt})$ and of $4.7^{\circ}$ at $\mathrm{O}(5) \ldots \mathrm{C}(16)=\mathrm{O}(6)(\mathrm{FullOpt})$. The Hopt- and Fullopt-models of calculation reproduce also some subtle details observed in crystal phase: first, the miminum approach C...O distances between molecules (I) (3.001 $\AA$; $2.997 \AA$ ) and (II) $(2.989 \AA ; 2.998 \AA)$ [symmetry codes: $(\mathrm{x}, \mathrm{y}, \mathrm{z})$ and $(-\mathrm{x}+0.5, \mathrm{y}+0.5, \mathrm{z})$ ] (respectively with the Hopt- and Full-opt models) are less to the sum of the Van der Waals radii which is assumed to be $3.2 \AA$ [47] and thus suggests the presence of stabilizing $\mathrm{C}=\mathrm{O} \ldots \mathrm{C}=\mathrm{O}$ intermolecular interactions between the corresponding pairs of symmetry-related of molecules (I) and (II). Second, the calculated non covalent $\theta$ angles between symmetryrelated of molecules (I)(Table 9) indicate only two values for $\theta$ angles $\left(87.3^{\circ}\right.$ and $\left.83^{\circ}\right)$ (with the Hopt-model) and $\left(86.2^{\circ}\right.$ and $83^{\circ}$ )(with Full-opt model) corresponding to $\varphi$ values out of the bisectorial criterium $\left(\varphi \cong 90^{\circ}\right)$ in good agreement with the experimental results. In the two latter cases, the nucleophilic oxygen is almost in closer contact with the electrophilic carbonyl groups and correspond to carbonyl groups forming dimmer held together by somewhat weaker $\mathrm{Nu}-\mathrm{El}$ dipole-dipole $\mathrm{C}=\mathrm{O} \ldots \mathrm{C}=\mathrm{O}$ interactions. The non-covalent $\theta$ angles (Table 8 ) between symmetry related molecules (II) indicate a $\theta$ value $\left(81.6^{\circ}\right.$ with the HOpt-model and $78.4^{\circ}$ with the FullOpt-model) which correspond to $\varphi$ value significantly deviated from the bisector criterium $\left(\varphi \cong 90^{\circ}\right)$ and therefore confirm the observation that the most significant intermolecular $\mathrm{C}=\mathrm{O} \ldots \mathrm{C}=\mathrm{O}$ interactions are essentially between symmetry-related of molecules (II) having their anhydride ring oriented in the same half space. Furthermore, the intermolecular contact between the symmetry related molecules (II) [symmetry codes: $(\mathrm{x}-0.5$, $0.5-y, 1-z)$ and $(-x+0.5, y+0.5, z)]$ are calculated to be quite large $[3.73 \AA-5.60 \AA]($ Hoptmodel) and in the range[3.60 $\AA-5.70 \AA]$ with in the Fullopt-model, with approach $\theta$ and $\varphi$ angles significantly deviated from $105^{\circ}$ and the bisector criterion respectively. The orientation of these pairs and the manner in which they overlap suggest localized electrostatic interactions each made up of an identical stack of molecules (II) (Fig.7 and Fig.8). These specific intermolecular interactions may be due simply to the tendency of the electron rich site of carbonyl group 1 to associate with the electron deficient of carbonyl group 2. The differences in environnements of the carbonyl groups of the symmetry-independent molecules (I) and (II) and the differences in their intermolecular associations in stacks appear to give rise to the variations in the geometrical parameters in going from the symmetry independent molecule (I) to (II) as reported in Table 8 .

But even more gratifying than the direct comparison is the agreement in many trends when crystal packing of 3,4,5,6-tetrahydrophthalic anhydride is compared to that of cis-1,2,3,6-THP anhydride: the shortest intermolecular $\mathrm{C}=\mathrm{O} \ldots \mathrm{C}=\mathrm{O}$ contacts in the 3,4,5,6-tetrahydrophthalic anhydride structure, in the range [2.957 $\AA$ to $3.191 \AA]$, are between symmetry related of 
formular group, while in cis-1,2,3,6-tetrahydrophthalic anhydride, the closest contacts [3.023 $\AA$ to $3.30 \AA$ ] appear among symmetry independent molecules. The calculated non covalent $\theta$ angles values corresponding to the $\mathrm{d}(\mathrm{C}=\mathrm{O} \ldots \mathrm{C}=\mathrm{O})$ abstraction distances in the 3,4,5,6-THP anhydride crystal packing deviate significantly from the ideal value which is assumed to be $105^{\circ}[13, \mathbf{1 4}]$ in comparison with the values calculated for cis-1,2,3,6-THP anhydride. The angles may be more accurate for $\mathrm{C}=\mathrm{O} \ldots \mathrm{C}=\mathrm{O}$ abstraction owing to the localisation of $\Pi$ electron density in the case of the cis-1,2,3,6-THP anhydride closer to the centre of the $\mathrm{C}=\mathrm{O}$ bond; a trend opposite to that expected for $\mathrm{C}=\mathrm{O} \ldots \mathrm{C}=\mathrm{O}$ abstraction in $3,4,5,6$ tetrahydrophthalic anhydride which may include electrostatic interactions as pointed out above. It is obvious that these differences in crystal packing between the two isomers are traceable to effects resulting from the presence of a double bond connecting two carbonyl groups which involve several factors. The first to be considered is the availability of a very low-lying unoccupied $\Pi$-orbital; thus anhydrides rings of 3,4,5,6-THP anhydrides may behave as $\Pi$-acceptors. Correspondingly, maleic anhydride has been known to form charge-transfer complexes with many aromatic molecules [48]. Second, the methine carbon alpha to the carbonyl group bears positive charges, and thus the electron-rich site of one anhydride ring may be attracted to the positive centre of another. These electronic properties, which are absent in cis-1,2,3,6-THP anhydride are assumed to affect the intermolecular interactions between formula groups of 3,4,5,6-tetrahydropthalic anhydride in a characteristic manner. This is confirmed by a comparison of the observed for both isomers reported in Table 2 and Table 8.

Lattice energy minimisation of the structures generated by a simulated annealing search in the most common space groups with one molecule in the asymmetric unit is shown in Fig. 9. The calculations suggest that experimental observed crystal structure with $Z^{\prime}=2$ of 3,4,5,6-THP anhydride is the most stable thermodynamically. The experimental observed structure is found lower in lattice energy than any of the computer-generated $Z^{\prime}=1$ structures. The lattice energies, densities, space groups and the cell dimensions of the ten lowest hypothetical structures with $Z^{\prime}=1$ are reported in Table 11.

Adding harmonic phonon estimates of the intermolecular zero point energy and entropy at the ambient temperature (Table 11) of 3,4,5,6-tetrahydrophthalic anhydride confirms the stability of the experimental observed $Z^{\prime}=2$ structure relative to the hypothetical structures with $Z=1$. Therefore, it seems, that the $Z^{\prime}=2$ packing for this molecule can simply explained on the basis of lattice energy searches. The results suggest that molecule's crystal structure is so favourable thermodynamically that other hypothetical structure with $Z^{\prime}=1$ as polymorphs are unlikely. Calculations are unable to find any alternative lower Z' polymorph and therefore we can conclude that the molecule exhibit packing difficulties may be because of its irregular and non-self-complementary molecular shape and frustration between close packing of bicyclic anhydride rings and strong directional intermolecular interactions.

\section{Discussion}

The results of calculations by lattice energy minimisations indicate that, for the two molecules studied here, the observed $Z^{\prime}=2$ structure is either the most thermodynamically stable structure or nearly isoenergetic with the best $Z^{\prime}=1$ packings. This finding argues against the suggestion that many high $Z$ ' polymorphs tend to be metastable fossil $[\mathbf{4 9}, \mathbf{5 0}]$ relics or forms of arrested crystallisations [51]. This example joins the other many cases of crystals where a higher Z' structure has been shown to be more stable than a Z'=1 polymorph [51-54]. This study confirms that high $Z$ ' crystals are also not 'on the way' or incompletely crystallized, they are fully crystalline, periodic ordered structures as also indicated by several researchers [55]. The observation of multiple molecules in the asymmetric unit may be 
explained by the fact that some of the intermolecular interactions in 3,4,5,6-THP are not compatible or not coincident with crystallographic symmetry. In this case it is the chemical nature of intermolecular interactions that drives the crystal molecular packing as suggested by other authors [55].

The calculated results obtained for cis-1,2,3,6-THP are less clear cut. The experimental structure is not the lowest in terms of calculated energy; the lattice energies of two hypothetical $Z^{\prime}=1$ structures are slightly more stable and this is enhanced by harmonic estimates of free energies. In contrast to 3,4,5,6-THP, this finding could fit the hypothesis that this structure may be considered as a metastable polymorph. The arrangement of molecules in the observed structure of Cis-1,2,3,6-THP may be a step on the way to the low Z' form. It is important to note that the calculated $Z^{\prime}=2$ structure exhibit lower density. This finding does not seem against the conception that high $Z$ ' structure may arise from discrete preassociated aggregates which should be less stable than putative (real) $Z^{\prime}=1$ thermodynamic form.

On the other hand, calculations predict a lot of structures that are not observed experimentally. Clearly, calculations predict that cis-1,2,3,6-THP anhydride could potentially have several polymorphs in contrast to 3,4,5,6-THP. Several authors have singled out the polymorphism as an indication of the appearance of a metastable structure as a result of solution aggregation factor [51, 57].The lack of polymorphism and the absence of driving forces toward $Z^{\prime}=1$ structure characterising essentially the crystal structure of 3,4,5,6-THP, may, thus, be the principle causes for the observation of multiple molecules in the asymmetric unit, predicted as the most thermodynamically stable structure, in comparison with cis1,2,3,5-THP anhydride. Both crystals exhibit strong directional $\mathrm{C}=\mathrm{O} \ldots \mathrm{C}=\mathrm{O}$ and weak $\mathrm{C}$ $\mathrm{H}$... O intermolecular interactions. This indicates that it is the molecular chemical nature of the intermolecular interactions that drives crystal packing in both crystals. The differences observed and detected between the two crystal packings, imply that it is not the $\mathrm{C}=\mathrm{O} \ldots \mathrm{C}=\mathrm{O}$ interactions alone that leads to the molecule crystallising with $Z^{\prime}=2$.

While minor conformational variations are observed and detected by calculations in symmetry independent molecules of both crystals, this is a result, rather than the cause of their being in different solid-state environments. For these molecules, the high $Z$ ' structure does not arisefrom the possibility of multiple molecular conformations. That the two molecules exhibit packing difficulties may be also because of their irregular and non-self-complementary molecular shape and/or frustration between close packing of anhydride rings and the strong directional intermolecular interactions discussed above.

\section{Conclusions}

A modelling study of cis-1,2,3,6- and 3,4,5,6-tetrahydrophthalic anhydride crystal structures using lattice energy calculations was presented. The calculated models are successful at reproducing the observed crystal structural differences between the two isomers. This is supported by the results of molecular calculations, which agree closely with the experimental observations and provide evidence that the distortion of molecules from their ideal geometries improves molecular packing in both crystals. The results of a search for minima in the lattice energy of both crystals amongst the more common space groups with $Z^{\prime}=1$ suggests that the experimental observed structure $\left(Z^{\prime}=2\right)$ for 3,4,5,6-tetrahydropthalic anhydride is more stable thermodynamically than the hypothetical structures with $Z^{\prime}=1$. Thus, the packing with $Z^{\prime}=2$, seems to be explained simply by thermodynamics.

In contrast, for cis-1,2,3,6-tetrahydrophthalic anhydride, calculation clearly predict that this compound could potentially have several polymorphs. The calculations predict several hypothetical structures with $Z^{\prime}=1$ which are thermodynamically slightly more stable than the 
observed structures. For this molecule, the observed structure with $Z^{\prime}=2$ cannot be explained simply on the basis of the energetic criterion. This study highlights the need for more theoretical and experimental collaboration to understand the factors that determine a molecule's crystal structure and polymorphic behaviour.

\section{Supplementary data}

The .Cif files of the ten lowest predicted structures with $Z^{\prime}=1$ of cis-1,2,3,6tetrahydrophthalic anhydride and the .Cif files of the observed structure of 3,4,5,6tetrahydrophthalic can be found in the supporting information. This is available free of charge via the Internet at http://link.springer.com.

\section{References}

1. Bailey ME, Amstutz ED (1956) Rearrangement of the Double Bond in cis-4Cyclohexene-1,2-dicarboxylic Anhydride. J Am Chem Soc 78(15): 3828-3830.

2. Ben Fredj A, Ben Rejeb S, Ben Amor F, Driss A (1998) L'anhydride cis-1,2,3,6Tétrahydrophtalique. Acta Cryst C54 : 1710 -1712.

3. Ben Fredj A (2000). Thèse de Doctorat en Chimie-Physique, Faculté des Sciences de Tunis, Tunisie.

4. Ben Fredj, Bagieu-Beucher M, Ben Rejeb S, Ben Lakhdar Z (2004) Structure of 3,4,5,6-tetrahydrophthalic anhydride at $-123^{\circ} \mathrm{C}$. Helvetica Chimica Acta 87: 1527-1535.

5. Ben Fredj A, Ben Rejeb S, Jaïdane N, Ben Lakhdar Z (2000) Conformational analysis of cis- $\Delta^{1},-\Delta^{2},-\Delta^{3}$ and $-\Delta^{4}$-tetrahydrophtalic anhydrides by semiempirical and ab initio molecular orbital calculations. J Mol Struct Theochem 528: 219-235.

6. Filippini G, Gramaccioli CM, Rovere C, Simonetta M Simonetta (1972) The structure of bicyclo[2,2,1]hept-5-ene-2,3-exo-dicarboxylic anhydride. Acta Cryst B 28: 2869-2874.

7. Destro R, Filippini G, Gramaccioli CM, Simonetta (1969) The structure of 5-norbornene2,3- endo-dicarboxylic anhydride. Acta Cryst B 25: 2465-2472.

8. Craig RER. Craig AC, Larsen RD, Caughlan CN (1976) Molecular geometry studies. Crystal and molecular structure of a 7-spirocyclopropylbicyclo[2.2.1] heptene anhydride. J Org Chem 41: 2129-2133.

9. Marsh RE, Ubell U, Wilcox HE Wilcox (1962) The crystal structure of maleic anhydride. Acta Cryst 15: 35-41.

10. Ehrenberg M (1965) The crystal structure of succinic anhydride. Acta Cryst 19: 698-703.

11. Craig RER, Craig AC, Larsen RD, Caughlan CN, Caughlan (1977) Molecular geometry studies. The crystal and molecular structure of a 7-spirocyclopentylbicyclo[2.2.1]heptene anhydride. J Org Chem 42: 3188-3190.

12. Destro R, Filippini G, Gramaccioli CM, Simonetta M Simonetta (1971) The structure of bicyclo[2,2,2]octene-2,3-endo-dicarboxylic anhydride. Acta Cryst B27: 2023-2028.

13. Ben Fredj A, Ben Rejeb S (1999) Interactions intermoléculaires et Gauchissement de la structure Cristalline de l'anhydride cis-1,2,3,6-tétrahydrophtalique. Journal de la Société Chimique de Tunisie, IV(6): 575-582.

14. Cossu M, Bachmann C, N'Guessan TY, Viani R, Lapasset J, Aycard, J-P, Bodot H(1987) Push-pull intermolecular nucleophile-electrophile interactions of carbonyl groups from 
crystallographic data and MNDO calculations. J Org Chem 52(24): 5313-5319.

15. Bolte M, Bauch C (1999) Cis1,2,3,6-Tetrahydropthalic anhydride at 173 K. Acta Cryst C55: 226-228.

16. Gavezzotti A (2008) Structure and energy in organic crystals with two molecules in the asymmetric unit: causality or chance? CrystEngComm 10: 389-398.

17. Anderson KM, Steed J W (2007) Comment on "On the presence of multiple molecules in the crystal asymmetric unit (Z'>1)” by Gautam R. Desiraju, CrystEngComm, 2007,9, 91. CrystEngComm 9: 328-330.

18. Price SL(2004) The computational prediction of pharmaceutical crystal structures and polymorphism. Adv Drug Deliv Rev 56(3): 301-319.

19. ChemBurkar S R, Bauer J, Deming K, Spiwek H, Patel K, Morris J, Henry R, Spanton S, Dziki W, Porter W, Quick J, Bauer P, Donaubauer J, Narayanan B A, Soldani M, Riley D, McFarland K (2000) Dealing with the impact of ritonavir polymorphs on the late stages of bulkdrug process development. Org Process Res Dev 4(5):413-417.

20. Holden JR, Du Z Y, Ammon HL (1993) Prediction of possible crystal structures for C, H-, N-, O-, and F-containing organic compounds. J Comput Chem 14: 422-437.

21. Day GM (2011), Crystallography Reviews, 17 (1), 3-52.

22. Beyer T, Lewis T, Price SL(2001) Which organic crystal

structures are predictable by lattice energy minimisation? CrystEngcomm 3(44): 178-212.

23. D. A. Bardwell, C. S. Adjiman, Y. A. Arnautova, E. Bartashevich, S. X. M. Boerrigter, D. E. Braun, A. J. Cruz-Cabeza, G. M. Day, R. G. Della Valle, G. R. Desiraju, B. P. van Eijck, J. C. Facelli, M. B. Ferraro, D. Grillo, M. Habgood, D. W. M. Hofmann, F. Hofmann, K. V. J. Jose, P. G. Karamertzanis, A. V. Kazantsev, J. Kendrick, L. N. Kuleshova, F. J. J. Leusen, A. V. Maleev, A. J. Misquitta, S. Mohamed, R. J. Needs, M. A. Neumann, D. Nikylov, A. M. Orendt, R. Pal, C. C. Pantelides, C. J. Pickard, L. S. Price, S. L. Price, H. A. Scheraga, J. van de Streek, T. S. Thakur, S. Tiwari, E. Venuti and I. K. Zhitkov (2011).

Acta Crystallographica B, 67, 535-551.

24. Amos RD with contributions from Alberts IL, Andrews JS, Colwell SM, Handy NC, Jayatilaka D, Knowles PJ, Kobayashi R, Koga N, Laidig KE, Maslen PE, Murray CW, Rice JE, Sanz J, Simandiras ED, Stone AJ, Su M-D (2001) CADPAC; version 6.5 Cambridge.

25. Stone AJ (1981) Distributed multipole analysis, or how to describe a molecular charge distribution. Chem. Phys. Lett 83(2): 233-239.

26. Stone AJ, Alderton M (1985) Distributed multipole analysis. Methods and applications. Mol Phys 56(5):1047-1064.

27. Williams DE (2001) Improved intermolecular force field for crystalline oxohydrocarbons including OHO hydrogen bonding. J Comp Chem 22: 1-20.

28. Williams DE (2001) Improved intermolecular force field for molecules containing H, C, $\mathrm{N}$, and $\mathrm{O}$ atoms, with application to nucleoside and peptide crystals. J Comp Chem 22: 1154-1166.

29. Coombes DS, Price SL, Willock DJ, Leslie M (1996) Role of Electrostatic Interactions in Determining the Crystal Structures of Polar Organic Molecules. A Distributed Multipole Study. J Phys Chem 100: 7352-7360

30. Price SL, Willock DJ, Leslie M, Day GM (2001) DMAREL, version 3.1.

31. Cerius2 (1997) Molecular Simulations Inc., San Diego.

32. Anghel AT, Day GM, Price SL(2002) A study of the known and hypothetical crystal structures of pyridine: why are there four molecules in the asymmetric unit cell? 
CrystEngComm 4(62): 348-355.

33. Bürgi HB, Dunitz JD, Shefter (1973) Geometrical reaction coordinates. II.

Nucleophilic addition to a carbonyl group. J Am Chem Soc 95: 5065-5067.

34. Bürgi HB, Lehn JM, Wipff G (1974) Ab initio study of nucleophilic addition to a carbonyl group. J Am Chem Soc 96: 1956-1957.

35 Steed KM., Steed, JW(2015) Packing Problems: High Z' Crystal Structures and Their Relationship to Cocrystals, Inclusion Compounds, and Polymorphism. Chem Rev 115: 28952933.

36 Hart H, Lin LTW,Ward DL(1984) J Am Chem Soc:106, 4043-4045.

37 Baggio S, Barriola A, de Perazzo PK (1972) Crystal and Molecular Structure of 7 Oxabicyclo[2,2,1] hept-5-ene-2,3-exo-dicarboxylic Anhydride. J Chem Soc Perkin Trans II: 934-938.

38 Kaftory M 1980) Configuration of Diels-Alder adducts. IV. Structures of configurationcontrolled monoadducts between certain propellanes and dienophiles. Acta Cryst B36: 597-606. 39Bartlett PD, Blakeney AJ, Kinura M, Watson WH (1980) Photooxidation of anti1,2,3,4,5,6,7,8-Octahydr1o,-4 ,5,8-dimethanonaphthalene ("Sesquinorbornene" ). Specific Steric Effects in the Hydrocarbon and Its Precursors. J Am Chem Soc 102: 1383-1390.

40 Hagenbuch, JP, Vogel P, Pinkerton A. A, Schwarzenbach D (1981) The $\pi$-Anisotropy of the Double Bond of a syn-11-Oxasesquinorbornene Derivative.. Stereoselectivity of the Diels-Alder additions of (2-norborneno)[c]furan. Crystal structure of 11-oxa-endotetracyclo[6.2.1.1 $\left.1^{3,6} \cdot 0^{2,7}\right]$-dodec-2(7)-ene-9,10-exo-dicarboxylic anhydride. Helv Chim Acta 64: 1818-1832.

41 Destro R, Filippini G, Gramaccioli CM, Simonetta M( 1971)The structure of bicyclo[2,2,2] octene-2,3-endo-dicarboxylic anhydride. Acta Cryst B27: 2023-2028.

42 Filippini G, Induni G, Simonetta M ( 1973) The crystal structure of antitricyclo[4,2,2,0 $\left.0^{2,5}\right]$ deca-3,9-diene-7,8-endo-dicarboxylic anhydride. Acta Cryst B29: 2471-2476. 43 Batas RB, Cutler RS(1977) Phthalic anhydride. Acta Cryst B33 : 893-895.

44 Fujdala KL, Oliver AG, Hollander FJ, Tilley TD (2003)Tris(tert-butoxy)siloxy derivatives of boron, including the boronous acid $\mathrm{HOB}[\mathrm{OSi}(\mathrm{O}(\mathrm{t}) \mathrm{Bu})(3)](2)$ and the metal (siloxy)boryloxide complex $\mathrm{Cp}(2) \mathrm{Zr}(\mathrm{Me}) \mathrm{OB}[\mathrm{OSi}(\mathrm{O}(\mathrm{t}) \mathrm{Bu})(3)](2)$ : a remarkable crystal structure with 18 independent molecules in its asymmetric unit. Inorg Chem 42: 1140-1150.

45 Braun B, Kalf I, Englert U(2011) One of the most complex "small molecule structures", ever reported: 16 independent molecules in the asymmetric unit for an ortho-palladated primary aminew. Chem Commun 47: 3846-3848.

46 Eijck BPV(2000) Ab Initio Crystal Structure Predictions for Flexible Hydrogen-Bonded Molecules. Part III. Effect of Lattice Vibrations. J Comp Chem 22: 816-826.

47 Nyman J, Day G M(2015) Static and lattice vibrational energy differences between polymorphs,. CrystEngComm, Advance Article, DOI: 10.1039/C5CE00045A.

47 Kitaigorodsky I(1961) Organic Chemical Crystallography, New York, (1961).

48 Crump RA, Price AH (1969) Dielectric Properties of Maleic and Phthalic Anhydride.

Charge-Transfer Complexes with Aromatic Hydrocarbons. Trans Faraday Soc 65:3195-3201

49 Anderson KM, Steed JW(2007) Comment on "On the presence of multiple molecules in the crystal asymmetric unit ( $\left.Z^{\prime}>1\right)$. CrystEngComm 9: 328-330.

50 Steed JW (2003) Should solid-state molecular packing have to obey the rules of

crystallographic symmetry? CrystEngComm 5: 169-179.

51 Desiraju GR (2007) On the presence of multiple molecules in the crystal asymmetric unit (Z'> 1). CrystEngComm 9: 91-92. 
52 Johnstone RDL, Ieva M, Lennie AR, McNab H, Pidcock E, Warren JE, Parsons S (2010) Pressure as a tool in crystal engineering: inducing a phase transition in a high- $Z$ ' structure. CrystEngComm 12: 2520-2523.

53 Damay F, Carretero-Genevrier A, Cousson A, Van Beek W, Rodriguez-Carvajal J, Fillaux $\mathrm{F}$ ( 2006) Synchrotron and neutron diffraction study of 4-methylpyridine-N-oxide at low temperature. Acta Cryst B62: 627-633.

54 Batsanov AS, Collings JC, Ward RM, Goeta AE, Porrès L, Beeby A, Howard JAK, Steed JW, Marder TB(2006) Crystal Engineering with Ethynylbenzenes 2: Structures of 4Trimethylsilylethynyl-N,N-dimethylaniline, and 4-Ethynyl-N,N-dimethylaniline with Z' $=12$ and a Single-Crystal to Single-Crystal Phase Transition at 122.5 \pm 2 K. CrystEngComm 8: 622628.

55 Bernstein J (2011) Polymorphism - A Perspective. Cryst. Growth Des 11: 632-650.

56 Pidcock $\mathrm{E}(2006)$ Spatial arrangement of molecules in homomolecular $Z=2$ structures. Acta Cryst B 62: 268-279.

57 Das D, Banerjee R, Mondal R, Howard JAK, Boese R, Desiraju GR(2006) Synthon evolution and unit cell evolution during crystallisation. A study of symmetry-independent molecules $\left(Z^{\prime}>1\right)$ in crystals of some hydroxy compounds. Chem Commun: 555-557. 


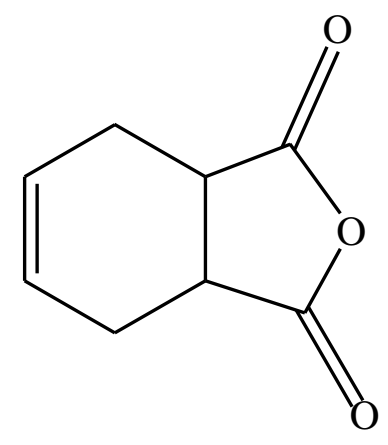

a)

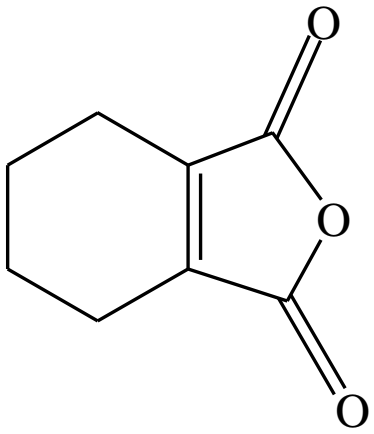

b)

Fig. 1 a) cis-1,2,3,6-tetrahydrophthalic anhydride ; b) 3,4,5,6-tetrahydropthalic anhydride. 


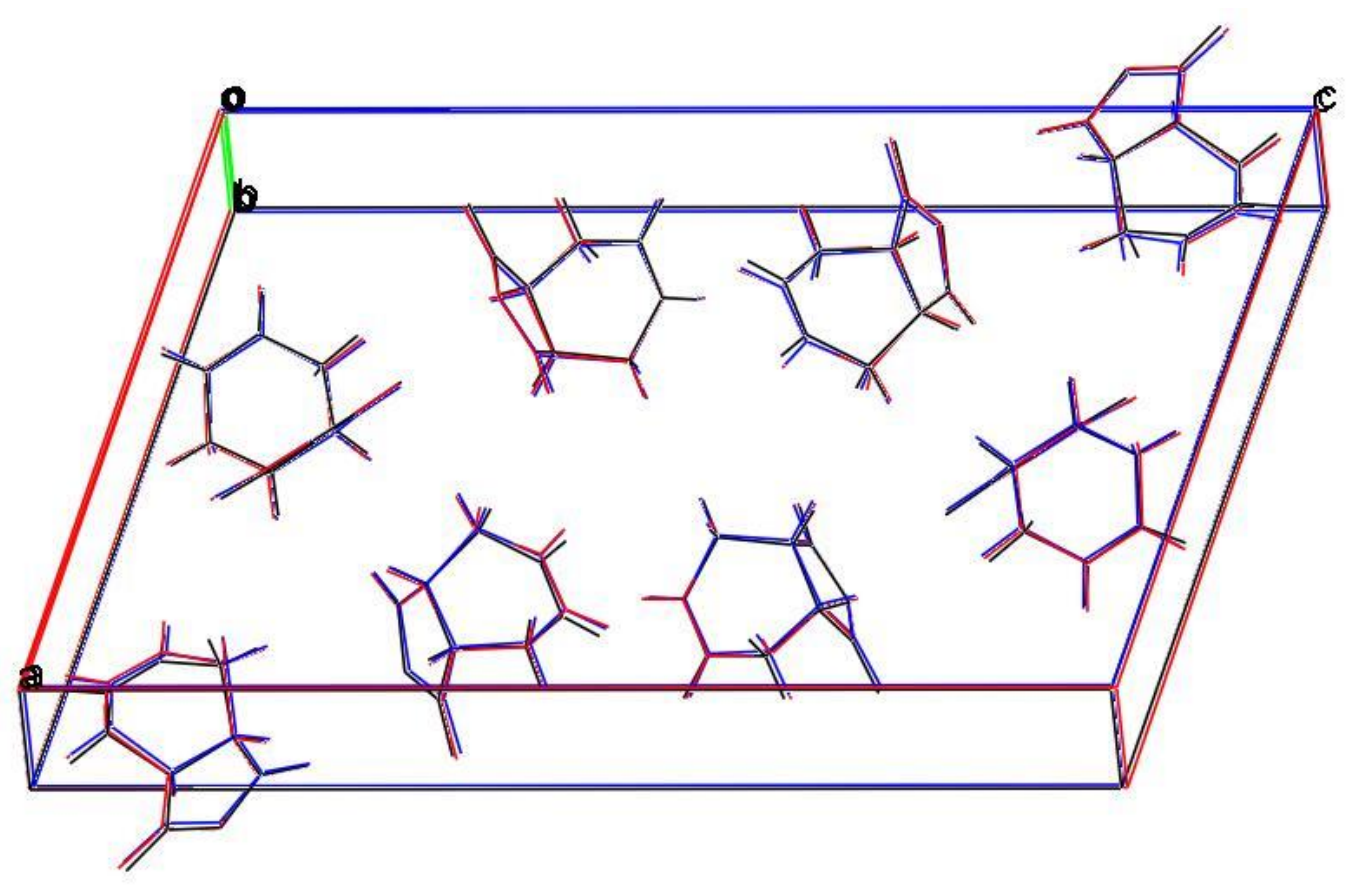

Fig. 2 Overlay of the observed (black) and energy minimized crystal structures of cis-1,2,3,6tetrahyrophthalic anhydride, using the Hopt (blue) and FullOpt (red) molecular models. 


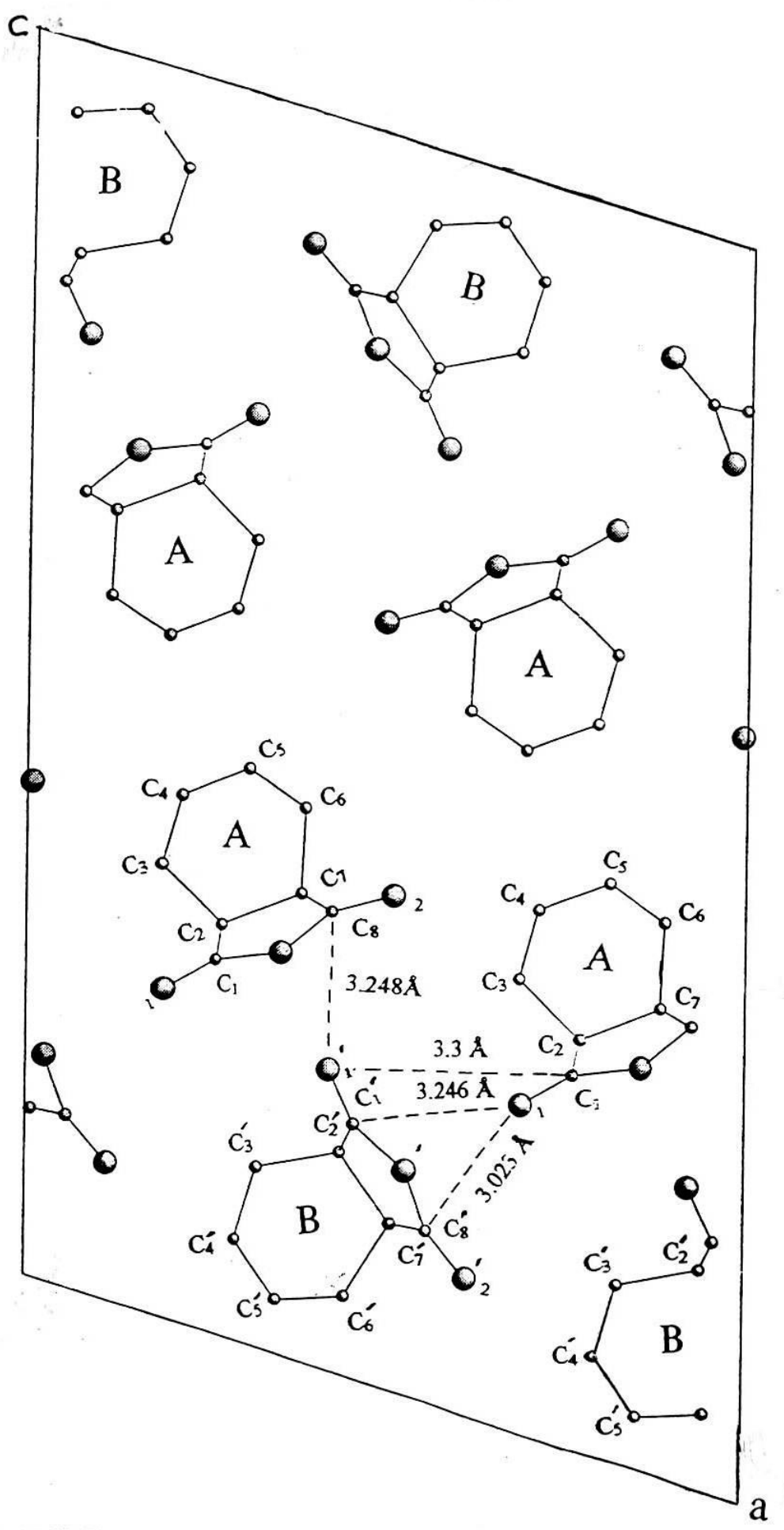

Fig. 3 Projection parallel to the axis b of the unit cell of the cis-1,2,3,6-tetrahydrophthalic anhydride observed in crystal phase, illustrating some of the observed $\mathrm{C}=\mathrm{O} \ldots \mathrm{C}=\mathrm{O}$ interactions. 
1,2,3,6-tetrahydrophthalic anhydride

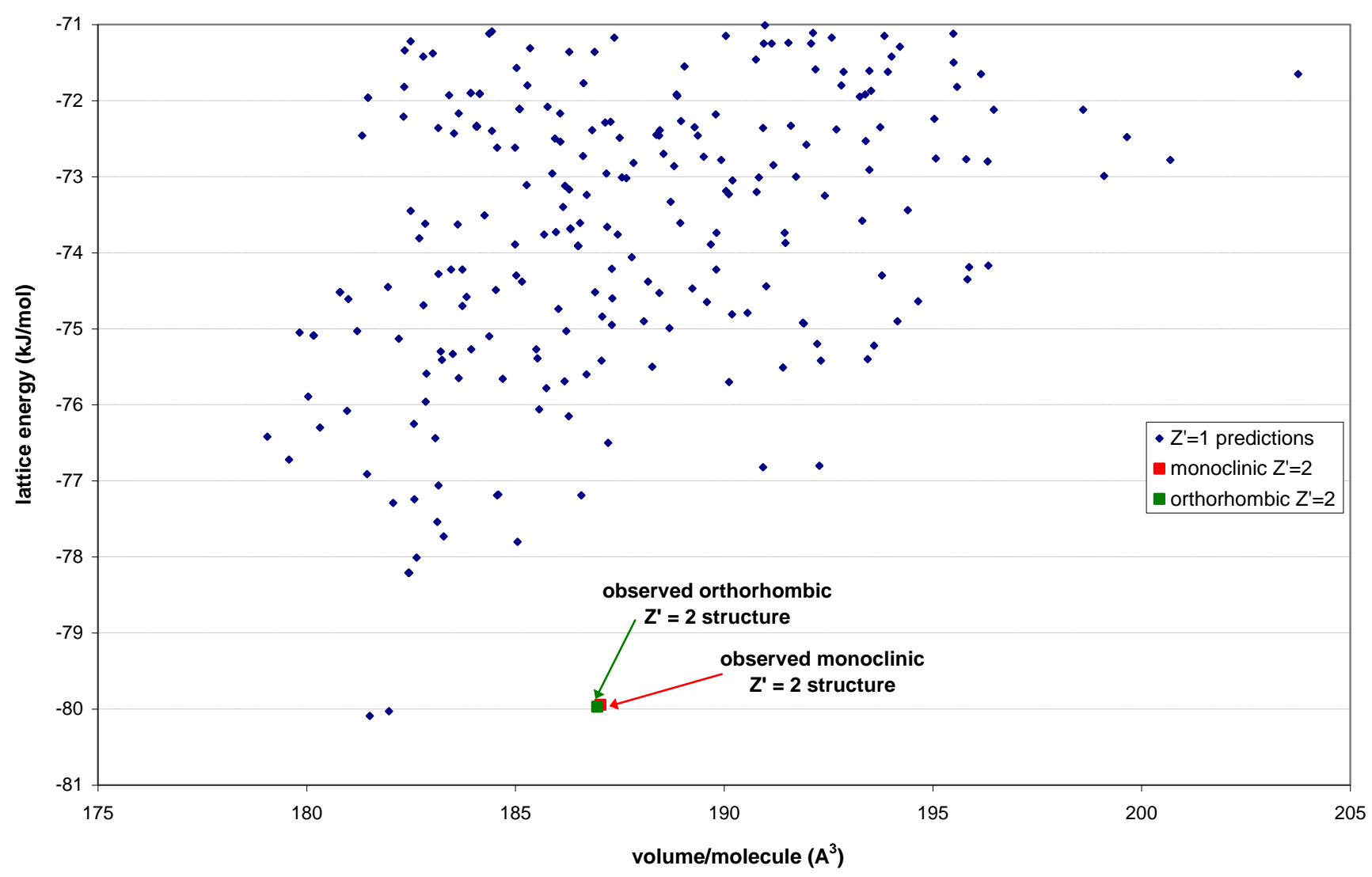

Fig. $4 Z^{\prime}=1$ computer-generated crystal structures vs observed $Z^{\prime}=2$ crystal structure. 


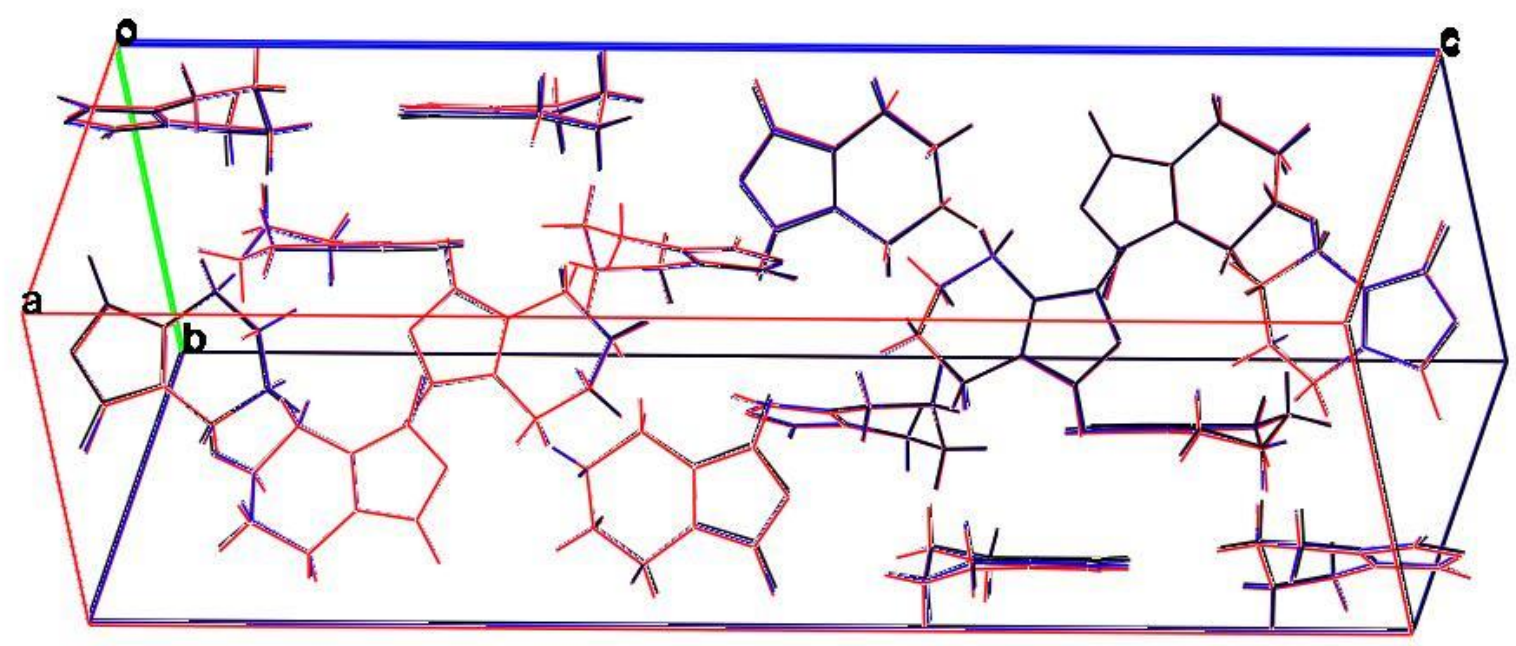

Fig. 5 Overlay of the observed (black) and energy minimized crystal structures of 3,4,5,6tetrahyrophthalic anhydride, using the Hopt (blue) and FullOpt (red) molecular models. 


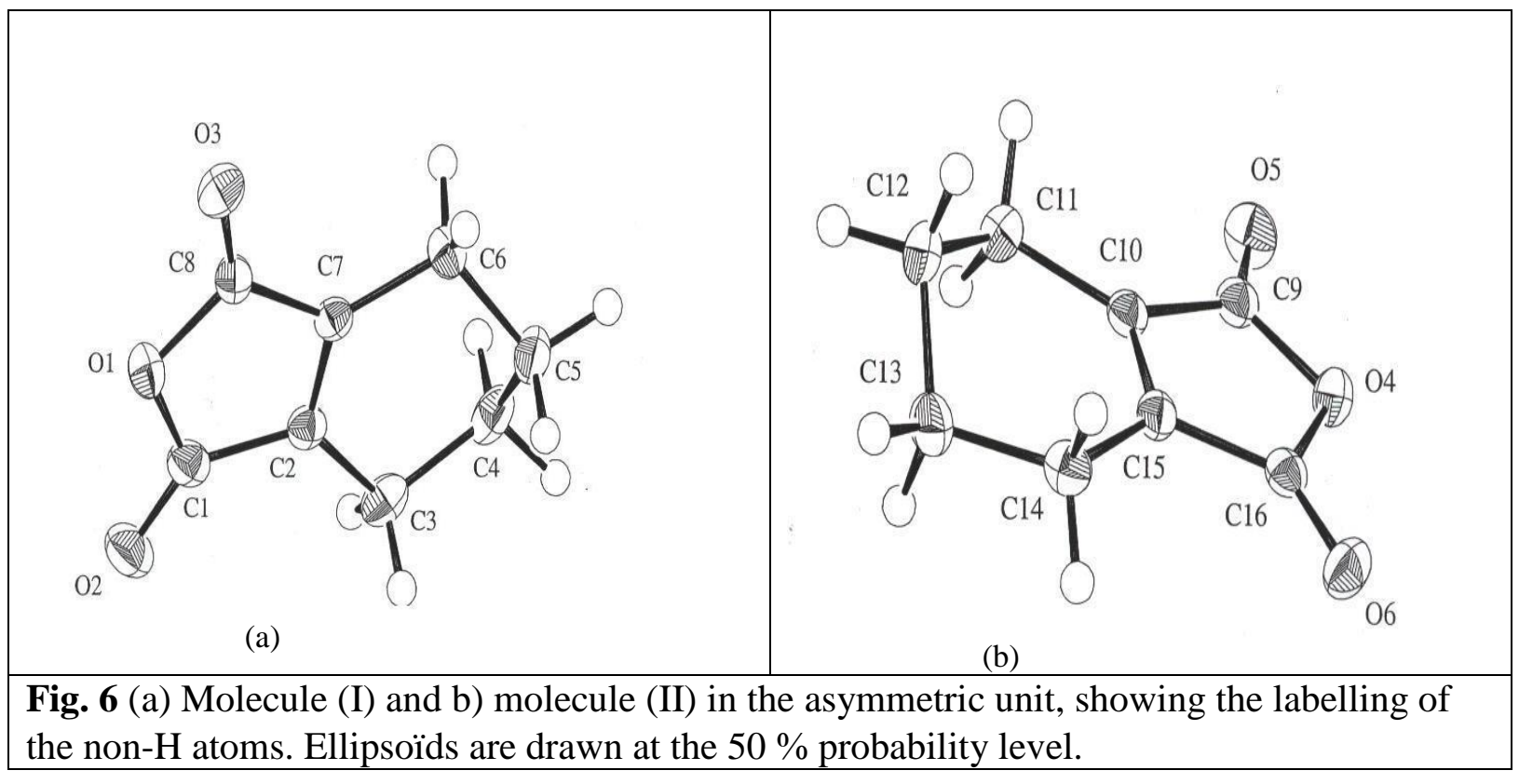




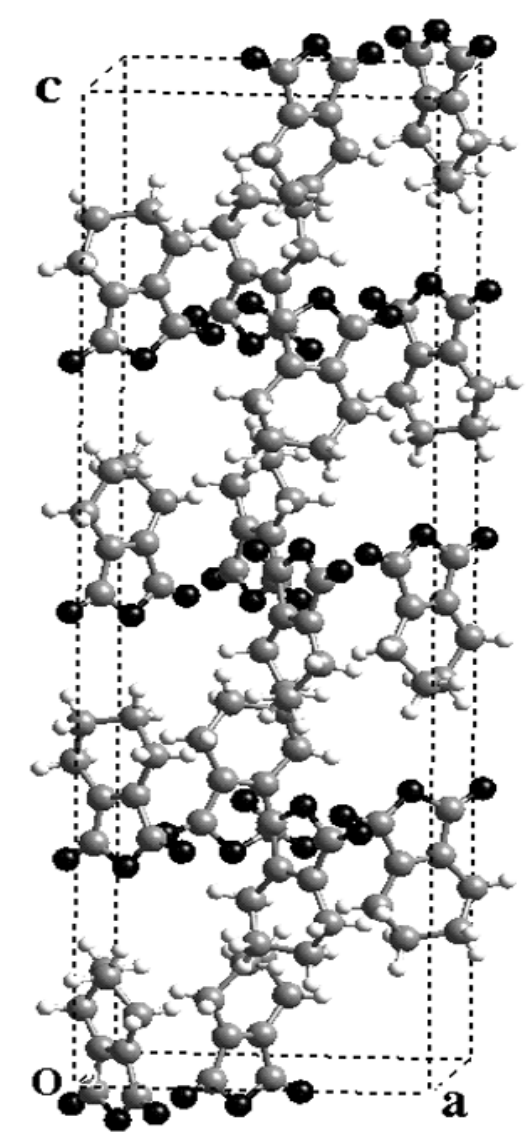

(a)

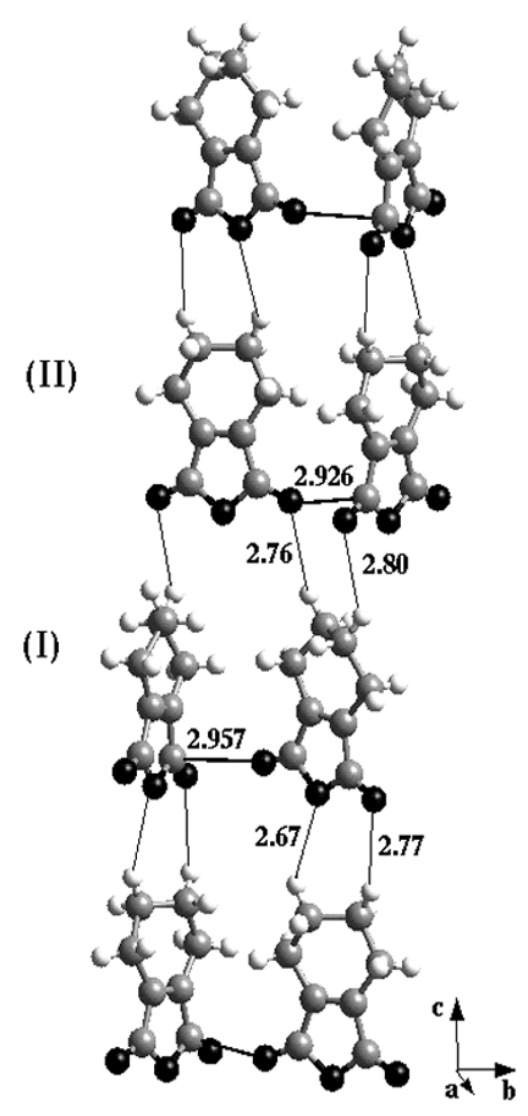

(b)

Fig. 7 (a) View of the observed structural arrangement down $\left[\begin{array}{lll}0 & 1 & 0\end{array}\right]$. Code for atoms: $\mathrm{O}=$ Black, $\mathrm{C}=$ grey, $\mathrm{H}=$ white. (b) Details of some $\mathrm{C}=\mathrm{O} \ldots \mathrm{C}=\mathrm{O}$ and $\mathrm{C}-\mathrm{H} \ldots \mathrm{O}$ interactions between molecules of 3,4,5,6-tetrahydrophthalic anhydride observed in crystal phase. 


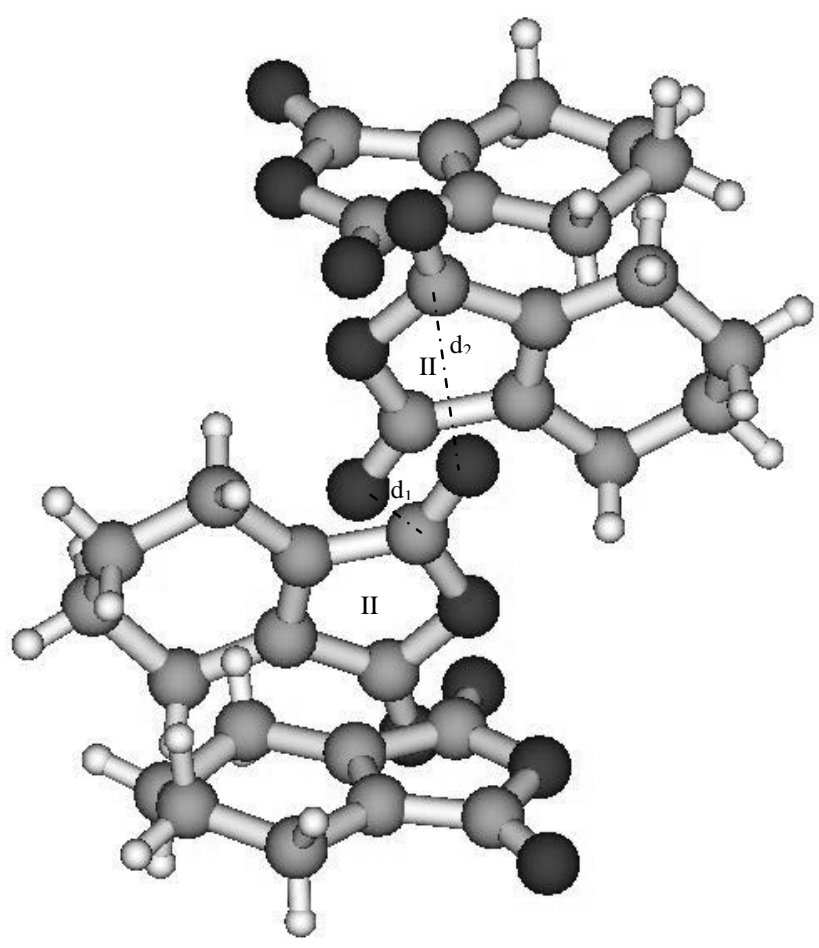

a

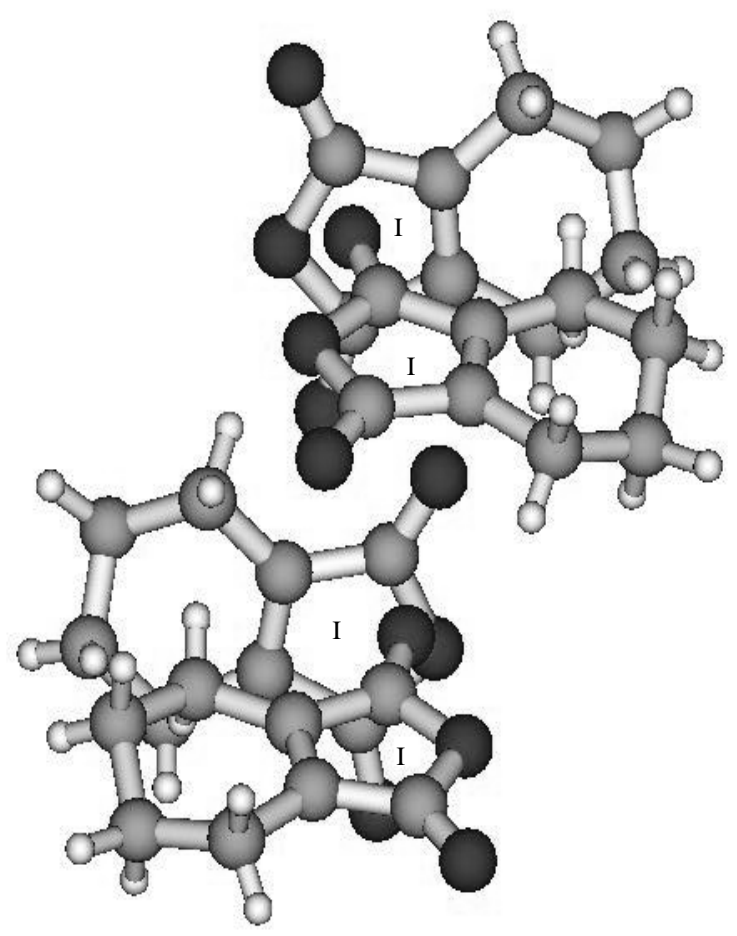

b

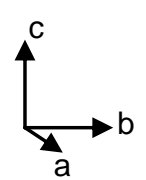

Fig. 8 (a)-Molecular arrangement of symmetry-dependent molecules (II) in crystal of 3,4,5,6-tetrahydrophthalic anhydride. $d_{1}=3.9 \AA$ and $d_{2}=5.71 \AA$. (b)-Molecular arrangement of symmetry-dependent molecules (I) in crystal of 3,4,5,6-tetrahydrophthalic anhydride. 
3,4,5,6-tetrahydrophthalic anhydride

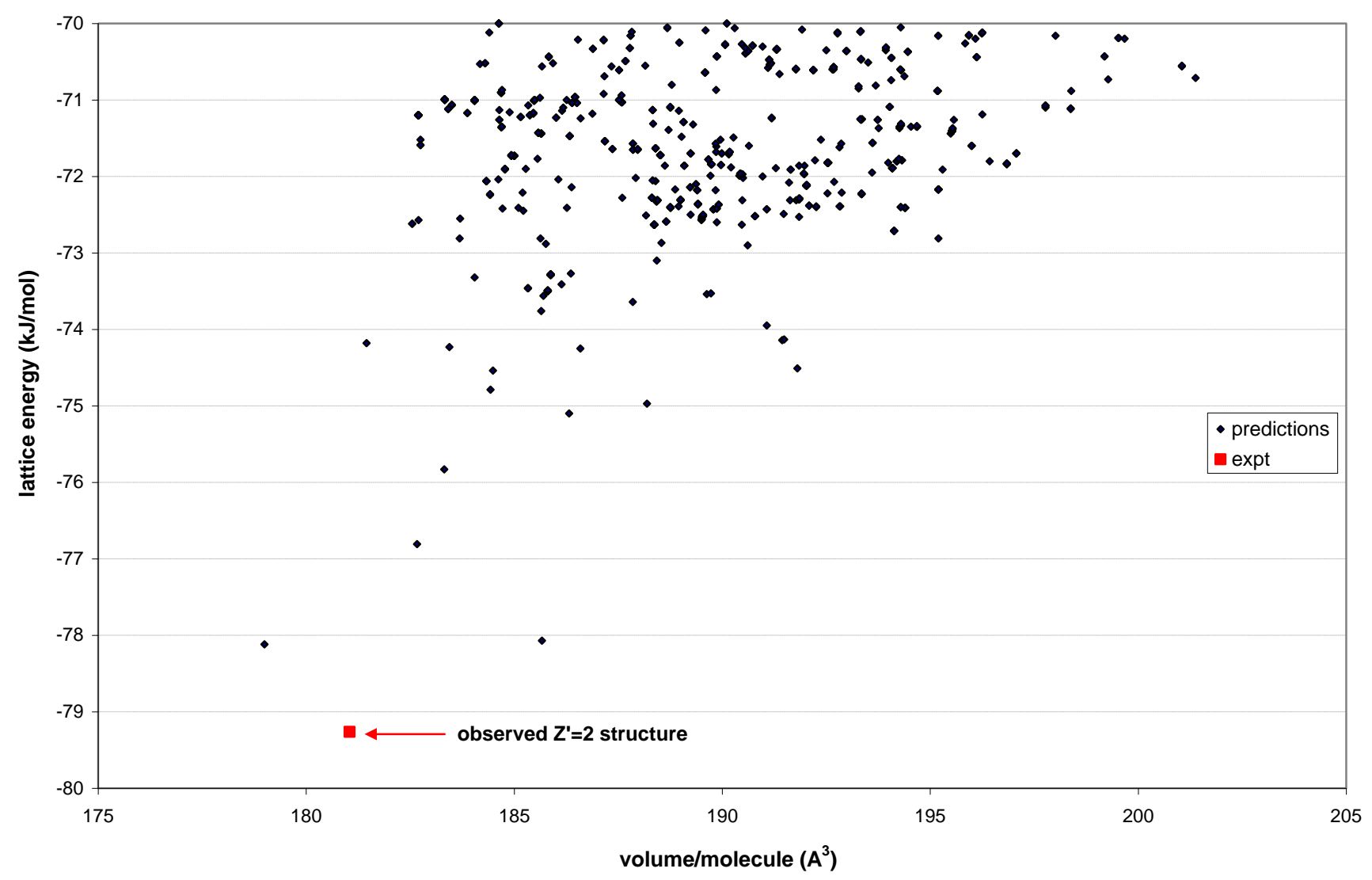

Fig. 9 Z'=1 computer-generated crystal structures vs observed $Z^{\prime}=2$ crystal structure. 
Tables

Table 1 X-ray and calculated values of unit cell parameters of cis-1,2,3,6-tetrahydrophthalic anhydride.

\begin{tabular}{cccc}
\hline Unit cell parameters & X-Ray [2] & HOpt-model & FullOpt-model \\
\hline $\mathrm{a}(\AA)$ & $13.385(4)$ & 13.184 & 13.297 \\
$\mathrm{~b}(\AA)$ & $5.215(1)$ & 5.249 & 5.276 \\
$\mathrm{c}(\AA)$ & $22.159(4)$ & 22.097 & 22.301 \\
$\alpha\left(^{\circ}\right)$ & 90 & 90 & 90 \\
$\beta\left(^{\circ}\right)$ & $107.29(4)$ & 107.03 & 106.97 \\
$\gamma\left({ }^{\circ}\right)$ & 90 & 90 & 90 \\
Volume $\left(\AA^{3}\right)$ & $1476.9(6)$ & 1461.97 & 1496.3 \\
Density $\left({\left.\mathrm{Mg} . \mathrm{m}^{-3}\right)}\right.$ & 1.369 & 1.382 & 1.351 \\
\hline
\end{tabular}

Table 2 Geometric parameters $\left(\AA{ }^{\circ}\right)$ relative to the asymmetric unit ( Molecule A and molecule B) of cis-1,2,3,6-tetrahydrophthalic anhydride determined by X-ray diffraction technique [2] and calculated using the FullOpt-model.

\begin{tabular}{|c|c|c|c|c|}
\hline \multicolumn{2}{|c|}{ Molecule (A) } & \multicolumn{2}{|c|}{ Molecule (B) } & \multirow[b]{2}{*}{ FullOpt-model } \\
\hline Bond lengths $[\AA]$ & $\mathrm{X}-\mathrm{Ray}[2]$ & Bond lengths $[\AA]$ & X-Ray[2] & \\
\hline $\mathrm{C}_{1}-\mathrm{O}_{1}$ & $1.185(3)$ & $\mathrm{C}^{\prime}{ }_{1}-\mathrm{O}^{\prime}{ }_{1}$ & $1.191(3)$ & 1.20 \\
\hline $\mathrm{C}_{1}-\mathrm{O}$ & $1.378(3)$ & $\mathrm{C}^{\prime}{ }_{1}-\mathrm{O}^{\prime}$ & $1.368(3)$ & 1.40 \\
\hline $\mathrm{C}_{1}-\mathrm{C}_{2}$ & $1.499(3)$ & $\mathrm{C}^{\prime}{ }_{1}-\mathrm{C}_{2}^{\prime}$ & $1.499(3)$ & 1.51 \\
\hline $\mathrm{C}_{2}-\mathrm{C}_{7}$ & $1.523(3)$ & $\mathrm{C}_{2}{ }_{2}-\mathrm{C}^{\prime}{ }_{7}$ & $1.527(3)$ & 1.54 \\
\hline $\mathrm{C}_{2}-\mathrm{C}_{3}$ & $1.535(3)$ & $\mathrm{C}_{2}^{\prime}-\mathrm{C}_{3}^{\prime}$ & $1.533(3)$ & 1.55 \\
\hline $\mathrm{C}_{3}-\mathrm{C}_{4}$ & $1.502(4)$ & $\mathrm{C}^{\prime}{ }_{3}-\mathrm{C}^{\prime}{ }_{4}$ & $1.500(4)$ & 1.49 \\
\hline $\mathrm{C}_{4}-\mathrm{C}_{5}$ & $1.303(4)$ & $\mathrm{C}^{\prime}{ }_{4}-\mathrm{C}_{5}$ & $1.305(4)$ & 1.34 \\
\hline $\mathrm{C}_{5}-\mathrm{C}_{6}$ & $1.477(4)$ & $\mathrm{C}_{5}{ }_{5}-\mathrm{C}^{\prime}{ }_{6}$ & $1.479(4)$ & 1.51 \\
\hline $\mathrm{C}_{6}-\mathrm{C}_{7}$ & $1.536(3)$ & $\mathrm{C}^{\prime}{ }_{6}-\mathrm{C}^{\prime}{ }_{7}$ & $1.539(3)$ & 1.54 \\
\hline $\mathrm{C}_{7}-\mathrm{C}_{8}$ & $1.500(3)$ & $\mathrm{C}_{7}{ }_{7}-\mathrm{C}^{\prime}{ }_{8}$ & $1.495(3)$ & 1.51 \\
\hline $\mathrm{C}_{8}-\mathrm{O}_{2}$ & $1.185(3)$ & $\mathrm{C}_{8}{ }_{8}-\mathrm{O}_{2}$ & $1.188(3)$ & 1.20 \\
\hline $\mathrm{C}_{8}-\mathrm{O}$ & $1.382(3)$ & $\mathrm{C}_{8}^{\prime}-\mathrm{O}^{\prime}$ & $1.382(3)$ & 1.39 \\
\hline Valence angles & & Valence angles $\left[{ }^{\circ}\right]$ & & \\
\hline$\left[{ }^{\circ}\right]$ & & & & \\
\hline $\mathrm{O}_{1}-\mathrm{C}_{1}-\mathrm{O}$ & $119.4(2)$ & $\mathrm{O}^{\prime}{ }_{1}-\mathrm{C}_{1}{ }_{1}-\mathrm{O}^{\prime}$ & $119.3(2)$ & 121.8 \\
\hline $\mathrm{O}-\mathrm{C}_{1}-\mathrm{C}_{2}$ & $129.9(2)$ & $\mathrm{O}^{\prime}-\mathrm{C}_{1}^{\prime}{ }_{1}-\mathrm{C}_{2}^{\prime}$ & $129.9(2)$ & 128.3 \\
\hline $\mathrm{C}_{1}-\mathrm{C}_{2}-\mathrm{C}_{7}$ & 104.3(2) & $\mathrm{C}^{\prime}{ }_{1}-\mathrm{C}_{2}{ }_{2}-\mathrm{C}^{\prime}{ }_{7}$ & $104.3(2)$ & 104.4 \\
\hline $\mathrm{C}_{7}-\mathrm{C}_{2}-\mathrm{C}_{3}$ & $113.8(2)$ & $\mathrm{C}^{\prime}{ }_{7}-\mathrm{C}^{\prime}{ }_{2}-\mathrm{C}^{\prime}{ }_{3}$ & $114.0(2)$ & 115.6 \\
\hline $\mathrm{C}_{4}-\mathrm{C}_{3}-\mathrm{C}_{2}$ & $109.6(2)$ & $\mathrm{C}_{4}^{\prime}-\mathrm{C}_{3}{ }_{3}-\mathrm{C}_{2}{ }_{2}$ & $109.9(2)$ & 111.2 \\
\hline $\mathrm{C}_{5}-\mathrm{C}_{4}-\mathrm{C}_{3}$ & $118.9(3)$ & $\mathrm{C}^{\prime}{ }_{5}-\mathrm{C}^{\prime}{ }_{4}-\mathrm{C}^{\prime}{ }_{3}$ & $119.7(3)$ & 119.4 \\
\hline $\mathrm{C}_{4}-\mathrm{C}_{5}-\mathrm{C}_{6}$ & $119.6(3)$ & $\mathrm{C}^{\prime}{ }_{4}-\mathrm{C}^{\prime}{ }_{5}-\mathrm{C}^{\prime}{ }_{6}$ & $119.6(3)$ & 120.4 \\
\hline $\mathrm{C}_{5}-\mathrm{C}_{6}-\mathrm{C}_{7}$ & $110.2(2)$ & $\mathrm{C}^{\prime}{ }_{5}-\mathrm{C}^{\prime}{ }_{6}-\mathrm{C}^{\prime}{ }_{7}$ & $109.9(2)$ & 111.4 \\
\hline $\mathrm{C}_{8}-\mathrm{C}_{7}-\mathrm{C}_{6}$ & $109.6(2)$ & $\mathrm{C}_{8}{ }_{8}-\mathrm{C}_{7}{ }_{7}-\mathrm{C}_{6}{ }_{6}$ & $109.9(2)$ & 110.6 \\
\hline Dihedral angles & & Dihedral angles & & \\
\hline$\left[{ }^{\circ}\right]$ & & {$\left[{ }^{\circ}\right]$} & & \\
\hline $\mathrm{C}_{2}-\mathrm{C}_{7}-\mathrm{C}_{6}-\mathrm{C}_{5}$ & 7(3) & $\mathrm{C}_{2}{ }_{2}-\mathrm{C}^{\prime}{ }_{7}-\mathrm{C}^{\prime}{ }_{6}-\mathrm{C}_{5}$ & $-43.8(3)$ & -39.8 \\
\hline
\end{tabular}




\begin{tabular}{|c|c|c|c|c|}
\hline $\mathrm{C}_{7}-\mathrm{C}_{6}-\mathrm{C}_{5}-\mathrm{C}_{4}$ & $45.2(4)$ & $\mathrm{C}_{7}^{\prime}-\mathrm{C}_{6}{ }_{6}-\mathrm{C}_{5}^{\prime}-\mathrm{C}_{4}^{\prime}$ & $44.8(4)$ & 42.6 \\
\hline $\left.\mathrm{C}_{6}-\mathrm{C}_{5}\right)-\mathrm{C}_{4}-\mathrm{C}_{3}$ & $1.4(4)$ & $\mathrm{C}_{6}{ }_{6}-\mathrm{C}_{5}{ }_{5}-\mathrm{C}^{\prime}{ }_{4}-\mathrm{C}_{3}$ & 1.1(4) & -0.3 \\
\hline $\mathrm{C}_{5}-\mathrm{C}_{4}-\mathrm{C}_{3}-\mathrm{C}_{2}$ & $-46.8(4)$ & $\mathrm{C}^{\prime}{ }_{5}-\mathrm{C}^{\prime}{ }_{4}-\mathrm{C}_{3}^{\prime}-\mathrm{C}_{2}$ & $-45.6(4)$ & -41.3 \\
\hline $\mathrm{C}_{4}-\mathrm{C}_{3}-\mathrm{C}_{2}-\mathrm{C}_{7}$ & $42.8(3)$ & $\mathrm{C}_{4}^{\prime}-\mathrm{C}_{3}^{\prime}-\mathrm{C}_{2}^{\prime}-\mathrm{C}_{7}^{\prime}$ & $41.2(3)$ & 39.5 \\
\hline $\mathrm{C}_{1}-\mathrm{C}_{2}-\mathrm{C} 7-\mathrm{C}_{8}$ & $1.4(2)$ & $\mathrm{C}^{\prime}{ }_{1}-\mathrm{C}_{2}{ }_{2}-\mathrm{C}^{\prime}{ }_{7}-\mathrm{C}_{8}^{\prime}$ & $1.9(2)$ & 0.4 \\
\hline $\mathrm{C}_{2}-\mathrm{C}_{7}-\mathrm{C}_{8}-\mathrm{O}$ & $-3.3(2)$ & $\mathrm{C}^{\prime}{ }_{2}-\mathrm{C}^{\prime}{ }_{7}-\mathrm{C}^{\prime}{ }_{8}-\mathrm{O}^{\prime}$ & $-2.2(2)$ & -1.6 \\
\hline $\mathrm{C}_{7}-\mathrm{C}_{8}-\mathrm{O}-\mathrm{C}_{1}$ & $3.9(2)$ & $\mathrm{C}^{\prime}{ }_{7}-\mathrm{C}^{\prime}{ }_{8}-\mathrm{O}^{\prime}-\mathrm{C}^{\prime}{ }_{1}$ & $1.6(3)$ & 2.2 \\
\hline $\mathrm{C}_{8}-\mathrm{O}-\mathrm{C}_{1}-\mathrm{C}_{2}$ & $-2.9(2)$ & $\mathrm{C}_{8}{ }_{8}-\mathrm{O}^{\prime}-\mathrm{C}^{\prime}{ }_{1}-\mathrm{C}_{2}{ }_{2}$ & $-0.3(2)$ & -1.9 \\
\hline $\mathrm{O}-\mathrm{C}_{1}-\mathrm{C}_{2}-\mathrm{C}_{7}$ & $0.8(2)$ & $\mathrm{O}^{\prime}-\mathrm{C}^{\prime}{ }_{1}-\mathrm{C}^{\prime}{ }_{2}-\mathrm{C}^{\prime}{ }_{7}$ & $-1.1(2)$ & 0.9 \\
\hline
\end{tabular}

Table 3 Results of lattice energy calculations for cis-1,2,3,6-and 3,4,5,6-tetrahydrophthalic anhydrides crystal structures.

\begin{tabular}{|c|c|c|c|c|}
\hline \multirow[t]{2}{*}{ Energy } & \multicolumn{2}{|c|}{$\begin{array}{c}\text { Cis-1,2,3,6-tetrahydrophthalic } \\
\text { anhydride }\end{array}$} & \multicolumn{2}{|c|}{$\begin{array}{c}\text { 3,4,5,6-tetrahydrophthalic } \\
\text { anhydride }\end{array}$} \\
\hline & $\begin{array}{l}\text { HOpt- } \\
\text { model }\end{array}$ & $\begin{array}{l}\text { FullOpt- } \\
\text { model }\end{array}$ & $\begin{array}{l}\text { HOpt- } \\
\text { model }\end{array}$ & $\begin{array}{l}\text { FullOpt- } \\
\text { model }\end{array}$ \\
\hline $\begin{array}{l}\text { Lattice energy } \\
\qquad\left(\mathrm{kJ} \cdot \mathrm{mol}^{-1}\right)\end{array}$ & -83.25 & -79.94 & -81.52 & -79.26 \\
\hline $\begin{array}{c}\text { Van der Waals } \\
\text { energy } \\
\left(\mathrm{kJ} \cdot \mathrm{mol}^{-1}\right)\end{array}$ & -53.09 & -52.20 & -59.10 & -58.21 \\
\hline $\begin{array}{l}\text { Electrostatic energy } \\
\qquad\left(\mathrm{kJ} \cdot \mathrm{mol}^{-1}\right)\end{array}$ & -30.16 & -27.74 & -22.42 & -21.05 \\
\hline
\end{tabular}


Table 4 Geometrical parameters $(\mathrm{d}, \theta$ and $\varphi)$ of the intermolecular $\mathrm{C}=\mathrm{O} \ldots \mathrm{C}=\mathrm{O}$ and $>\mathrm{O} \ldots \mathrm{C}=\mathrm{O}$ interactions in cis-1,2,3,6-tetrahydrophthalic anhydride observed by X-Ray technique [2] and calculated using the Hopt- and FullOpt-models.

\begin{tabular}{|c|c|c|c|c|c|c|c|c|c|c|}
\hline \multirow[b]{2}{*}{$\begin{array}{c}\mathrm{C}=\mathrm{O} \ldots \mathrm{C}=\mathrm{O} \\
\text { and }>\mathrm{O} \ldots \mathrm{C}=\mathrm{O}\end{array}$} & \multirow[b]{2}{*}{ Type } & \multicolumn{3}{|c|}{$\mathrm{d}(\mathrm{O} \ldots \mathrm{C})[\AA]$} & \multicolumn{3}{|c|}{$\theta(\mathrm{O} \ldots \mathrm{CO})\left[^{\circ}\right]$} & \multicolumn{3}{|c|}{$\varphi(\mathrm{O} \ldots \mathrm{COC})\left[^{\circ}\right]$} \\
\hline & & $\begin{array}{l}\text { HOpt- } \\
\text { model }\end{array}$ & $\mathrm{X}$-Ray[2] & $\begin{array}{l}\text { FullOpt- } \\
\text { model }\end{array}$ & $\begin{array}{c}\text { HOpt- } \\
\text { model }\end{array}$ & X-Ray[2] & $\begin{array}{l}\text { FullOpt } \\
\text {-model }\end{array}$ & $\begin{array}{c}\text { HOpt- } \\
\text { model }\end{array}$ & X-Ray[2] & $\begin{array}{l}\text { FullOpt } \\
\text {-model }\end{array}$ \\
\hline $\mathrm{C}_{1}=\mathrm{O}_{1} \ldots . . \mathrm{C}_{1}{ }_{1}=\mathrm{O}^{\prime}{ }_{1}$ & A-B & 3.197 & $3.246(3)$ & 3.219 & 114.5 & $117.03(17)$ & 116.2 & 99.4 & 98.61(28) & 97.4 \\
\hline $\mathrm{C}_{1}=\mathrm{O}_{1} \ldots \mathrm{C}^{\prime}{ }_{8}=\mathrm{O}^{\prime}{ }_{2}$ & A-B & 3.062 & $3.023(3)$ & 3.060 & 109.5 & $108.21(18)$ & 109.9 & 84.8 & $87.79(28)$ & 86.5 \\
\hline $\mathrm{C}^{\prime}{ }_{1}=\mathrm{O}^{\prime}{ }_{1} \ldots \mathrm{C}_{8}=\mathrm{O}_{2}$ & A-B & 3.364 & $3.248(3)$ & 3.338 & 117 & $115.18(16)$ & 115 & 91.8 & $88.95(27)$ & 93.4 \\
\hline $\mathrm{C}^{\prime}{ }_{1}=\mathrm{O}^{\prime}{ }_{1} \ldots \mathrm{C}_{1}=\mathrm{O}_{1}$ & A-B & 3.324 & $3.30(3)$ & 3.331 & 115 & $116.98(17)$ & 114.7 & 89.4 & $89.90(27)$ & 86.7 \\
\hline$>\mathrm{O} \ldots \ldots \mathrm{C}_{1}{ }_{1}=\mathrm{O}{ }_{1}$ & A-B & 4.025 & $3.973(3)$ & 4.009 & 62.1 & $62.56(14)$ & 60.6 & 22.6 & $55.31(27)$ & 138.2 \\
\hline$>\mathrm{O}^{\prime} \ldots \mathrm{C}_{8}=\mathrm{O}^{\prime}{ }_{1}$ & A-B & 5.134 & $4.981(3)$ & 5.120 & 99.9 & $96.83(15)$ & 96.9 & 83.2 & $96.23(25)$ & 85.5 \\
\hline$>\mathrm{O}^{\prime} \ldots . . \mathrm{C}_{1}=\mathrm{O}^{\prime}{ }_{1}$ & A-B & 3.783 & $3.747(3)$ & 3.771 & 44.8 & $48.70(14)$ & 45.5 & 23.1 & $24.69(32)$ & 22.7 \\
\hline
\end{tabular}


Table 5 Density, space group, lattice energy (Elatt), zero point energy ( ZPE) and total vibrational contributions to free energy (Fvib) of the observed structures and the ten lowest hypothetical $Z^{\prime}=1$ structures of cis-1,2,3,6-tetrahydropthalic anhydride.

\begin{tabular}{|c|c|c|c|c|c|c|c|c|c|c|c|c|c|}
\hline Structure & density & $\begin{array}{l}\text { Space } \\
\text { group }\end{array}$ & $\mathrm{a}$ & b & $\mathrm{c}$ & $\alpha$ & $\beta$ & $\gamma$ & Elatt & $\mathrm{ZPE}$ & $\begin{array}{c}\text { Elatt }+ \\
\text { ZPE }\end{array}$ & $\begin{array}{l}\text { Fvib } \\
298 K\end{array}$ & $\begin{array}{c}\mathrm{A} \\
298 \mathrm{~K}\end{array}$ \\
\hline Pred 1 & 1.392 & $P 2_{1} / a$ & 15.105 & 5.046 & 12.111 & 90 & 51.32 & 90 & -80.09 & 2.00 & -78.09 & -21.35 & -101.44 \\
\hline Pred 2 & 1.388 & $P 2_{1} 2_{1} 2_{1}$ & 5.047 & 11.830 & 12.190 & 90 & 90 & 90 & -80.03 & 1.99 & -78.04 & -21.40 & -101.43 \\
\hline $\begin{array}{c}\text { Expt } \\
\text { monoclin } \\
\text { ic }\end{array}$ & 1.351 & $\begin{array}{c}P 2_{1} / a \\
Z^{\prime}=2\end{array}$ & 13.297 & 5.276 & 22.301 & 90 & 106.97 & 90 & -79.97 & 2.11 & -77.86 & -19.73 & -99.70 \\
\hline $\begin{array}{c}\text { Expt } \\
\text { orthorho } \\
\text { mbic } \\
\end{array}$ & 1.351 & $\begin{array}{c}P c a 2_{1}, \\
Z^{\prime}=2\end{array}$ & 13.306 & 5.285 & 21.267 & 90 & 90 & 90 & -79.94 & 2.10 & -77.84 & -19.79 & -99.73 \\
\hline Pred 3 & 1.385 & $P-1$ & 5.258 & 13.064 & 6.598 & 60.17 & 68.76 & 80.28 & -78.21 & 2.09 & -76.12 & -19.52 & -97.73 \\
\hline Pred 4 & 1.383 & $C 2 / c$ & 25.410 & 5.062 & 12.296 & 90 & 112.52 & 90 & -78.01 & 2.16 & -75.85 & -19.52 & -97.53 \\
\hline Pred 5 & 1.365 & $P 2_{1} 2_{1} 2_{1}$ & 6.706 & 8.467 & 13.040 & 90 & 90 & 90 & -77.80 & 1.98 & -75.82 & -20.59 & -98.39 \\
\hline Pred 6 & 1.378 & $P 2_{1} / c$ & 12.003 & 6.793 & 9.429 & 90 & 107.53 & 90 & -77.73 & 2.15 & -75.58 & -19.48 & -97.21 \\
\hline Pred 7 & 1.380 & $P 2{ }_{1} 2_{1} 2_{1}$ & 5.077 & 11.937 & 12.085 & 90 & 90 & 90 & -77.54 & 2.18 & -75.36 & -19.57 & -97.11 \\
\hline Pred 8 & 1.388 & $P b c a$ & 6.743 & 9.140 & 23.634 & 90 & 90 & 90 & -77.29 & 2.12 & -75.17 & -20.12 & -97.41 \\
\hline Pred 9 & 1.384 & $P 2_{1}$ & 7.828 & 5.535 & 8.429 & 90 & 90.98 & 90 & -77.24 & 2.17 & -75.07 & -19.61 & -96.85 \\
\hline Pred 10 & 1.369 & $P 2{ }_{1} 2_{1} 2_{1}$ & 5.090 & 9.597 & 15.113 & 90 & 90 & 90 & -77.19 & 2.02 & -75.17 & -20.46 & -97.65 \\
\hline
\end{tabular}


Table 6 X-ray and calculated values of unit cell parameters of 3,4,5,6-tetrahydrophthalic anhydride.

\begin{tabular}{cccc}
\hline Unit cell parameters & X-Ray[4] & HOpt-model & FullOpt-model \\
\hline $\mathrm{a}(\AA)$ & $9.7936(2)$ & 9.914 & 9.986 \\
$\mathrm{~b}(\AA)$ & $9.0338(1)$ & 9.136 & 9.166 \\
$\mathrm{c}(\AA)$ & $31.7069(6)$ & 31.631 & 31.647 \\
$\alpha\left({ }^{\circ}\right)$ & 90 & 90 & 90 \\
$\beta\left(^{\circ}\right)$ & 90 & 90 & 90 \\
$\gamma\left(\left(^{\circ}\right)\right.$ & 90 & 90 & 90 \\
Volume $\left(\AA^{3}\right)$ & $2805.22(7)$ & 2865.15 & 2896.76 \\
Density $\left({\left.\mathrm{Mg} . \mathrm{m}^{-3}\right)}\right.$ & 1.441 & 1.411 & \\
\hline
\end{tabular}

Table 7 Selected Geometric Parameters $\left(\AA{ }^{\circ}\right)$ relative to the asymmetric unit ( Molecule I and molecule II) of 3,4,5,6-Tetrahydrophthalic Anhydride determined by X-ray diffraction technique [4] and calculated using the FullOpt-model.

\begin{tabular}{|c|c|c|c|c|}
\hline \multicolumn{2}{|c|}{ Molecule (I) } & \multicolumn{2}{|c|}{ Molecule (II) } & \multirow[b]{2}{*}{ FullOpt-model } \\
\hline Bond lengths $[\AA]$ & X-Ray[4] & Bond lengths $[\AA]$ & X-Ray[4] & \\
\hline $\mathrm{O}_{1}-\mathrm{C}_{8}$ & $1.396(2)$ & $\mathrm{O}_{4}-\mathrm{C}_{9}$ & $1.399(2)$ & 1.39 \\
\hline $\mathrm{O}_{1}-\mathrm{C}_{1}$ & $1.401(2)$ & $\mathrm{O}_{4}-\mathrm{C}_{16}$ & $1.396(2)$ & 1.39 \\
\hline $\mathrm{O}_{2}-\mathrm{C}_{1}$ & $1.193(2)$ & $\mathrm{O}_{5}-\mathrm{C}_{9}$ & $1.193(2)$ & 1.19 \\
\hline $\mathrm{O}_{3}-\mathrm{C}_{8}$ & $1.192(2)$ & $\mathrm{O}_{6}-\mathrm{C}_{16}$ & $1.193(2)$ & 1.19 \\
\hline $\mathrm{C}_{1}-\mathrm{C}_{2}$ & $1.472(2)$ & $\mathrm{C}_{16}-\mathrm{C}_{15}$ & $1.474(3)$ & 1.48 \\
\hline $\mathrm{C}_{2}-\mathrm{C}_{7}$ & $1.331(3)$ & $\mathrm{C}_{15}-\mathrm{C}_{10}$ & $1.332(3)$ & 1.33 \\
\hline $\mathrm{C}_{7}-\mathrm{C}_{8}$ & $1.474(3)$ & $\mathrm{C}_{9}-\mathrm{C}_{10}$ & $1.480(3)$ & 1.48 \\
\hline $\mathrm{C}_{2}-\mathrm{C}_{3}$ & $1.487(3)$ & $\mathrm{C}_{14}-\mathrm{C}_{15}$ & $1.487(3)$ & 1.49 \\
\hline $\mathrm{C}_{3}-\mathrm{C}_{4}$ & $1.526(3)$ & $\mathrm{C}_{13}-\mathrm{C}_{14}$ & $1.528(3)$ & 1.53 \\
\hline $\mathrm{C}_{4}-\mathrm{C}_{5}$ & $1.527(3)$ & $\mathrm{C}_{12}-\mathrm{C}_{13}$ & $1.531(3)$ & 1.51 \\
\hline $\mathrm{C}_{5}-\mathrm{C}_{6}$ & $1.528(3)$ & $\mathrm{C}_{11}-\mathrm{C}_{12}$ & $1.530(3)$ & 1.54 \\
\hline $\mathrm{C}_{6}-\mathrm{C}_{7}$ & $1.487(3)$ & $\mathrm{C}_{10}-\mathrm{C}_{11}$ & $1.490(3)$ & 1.48 \\
\hline Valence angles $\left[{ }^{\circ}\right.$ ] & & Valence angles $\left[{ }^{\circ}\right]$ & & \\
\hline $\mathrm{C}_{1}-\mathrm{O}_{1}-\mathrm{C}_{8}$ & $107.5(1)$ & $\mathrm{C}_{9}-\mathrm{O}_{4}-\mathrm{C}_{16}$ & $107.6(1)$ & 106.8 \\
\hline $\mathrm{C}_{8}-\mathrm{C}_{7}-\mathrm{C}_{2}$ & $108.5(2)$ & $\mathrm{C}_{9}-\mathrm{C}_{10}-\mathrm{C}_{15}$ & $108.0(2)$ & 108.3 \\
\hline $\mathrm{O}_{2}-\mathrm{C}_{1}-\mathrm{O}_{1}$ & $120.3(2)$ & $\mathrm{O}_{6}-\mathrm{C}_{16}-\mathrm{O}_{4}$ & $121.0(2)$ & 121.3 \\
\hline $\mathrm{C}_{7}-\mathrm{C}_{6}-\mathrm{C}_{5}$ & $108.8(2)$ & & 109.3(2) & 110.6 \\
\hline & & $\mathrm{C}_{10}-\mathrm{C}_{11}-\mathrm{C}_{12}$ & & \\
\hline $\mathrm{C}_{6}-\mathrm{C}_{5}-\mathrm{C}_{4}$ & $112.1(2)$ & & $112.3(2)$ & 112.0 \\
\hline & & $\mathrm{C}_{11}-\mathrm{C}_{12}-\mathrm{C}_{13}$ & & \\
\hline $\mathrm{C}_{4}-\mathrm{C}_{3}-\mathrm{C}_{2}$ & $109.8(2)$ & & $109.6(2)$ & 110.9 \\
\hline & & $\mathrm{C}_{13}-\mathrm{C}_{14}-\mathrm{C}_{15}$ & & \\
\hline $\mathrm{C}_{3}-\mathrm{C}_{2}-\mathrm{C}_{7}$ & $125.4(2)$ & & $124.8(2)$ & 124.8 \\
\hline & & $\mathrm{C}_{14}-\mathrm{C}_{15}-\mathrm{C}_{10}$ & & \\
\hline $\mathrm{C}_{2}-\mathrm{C}_{7}-\mathrm{C}_{6}$ & $124.9(2)$ & & $125.4(2)$ & 124.1 \\
\hline Dihedral angles $\left[{ }^{\circ}\right]$ & & $\begin{array}{c}\mathrm{C}_{11}-\mathrm{C}_{10}-\mathrm{C}_{15} \\
\text { Dihedral } \\
\text { angles }\left[\left[^{\circ}\right]\right.\end{array}$ & & \\
\hline $\mathrm{O}_{1}-\mathrm{C}_{8}-\mathrm{C}_{7}-\mathrm{C}_{2}$ & $-0.2(2)$ & & $-2.3(2)$ & 0.4 \\
\hline
\end{tabular}




\begin{tabular}{|c|c|c|c|c|}
\hline \multirow[b]{2}{*}{$\mathrm{C}_{8}-\mathrm{C}_{7}-\mathrm{C}_{2}-\mathrm{C}_{1}$} & \multicolumn{2}{|r|}{$\mathrm{O}_{4}-\mathrm{C}_{9}-\mathrm{C}_{10}-\mathrm{C}_{15}$} & \multirow[b]{2}{*}{$0.9(2)$} & \multirow[b]{2}{*}{-0.6} \\
\hline & $0.2(2)$ & $\mathrm{C}_{9}-\mathrm{C}_{10}-\mathrm{C}_{15}-\mathrm{C}_{1}$ & & \\
\hline $\mathrm{O}_{1}-\mathrm{C}_{1}-\mathrm{C}_{2}-\mathrm{C}_{7}$ & $-0.1(2)$ & & $0.9(2)$ & 0.6 \\
\hline $\mathrm{C}_{2}-\mathrm{C}_{1}-\mathrm{O}_{1}-\mathrm{C}_{8}$ & $-0.1(2)$ & $\begin{array}{l}\mathrm{O}_{4}-\mathrm{C}_{16}-\mathrm{C}_{15}-\mathrm{C}_{10} \\
\mathrm{C}_{9}-\mathrm{O}_{4}-\mathrm{C}_{16}-\mathrm{C}_{15}\end{array}$ & $-2.4(2)$ & 0.3 \\
\hline $\mathrm{C}_{3}-\mathrm{C}_{2}-\mathrm{C}_{7}-\mathrm{C}_{6}$ & $-0.6(3)$ & $\mathrm{C}_{11}-\mathrm{C}_{10}-\mathrm{C}_{15}-\mathrm{C}_{14}$ & $1.2(3)$ & -0.4 \\
\hline $\mathrm{C}_{2}-\mathrm{C}_{7}-\mathrm{C}_{6}-\mathrm{C}_{5}$ & $-16.8(3)$ & $\mathrm{C}_{12}-\mathrm{C}_{11}-\mathrm{C}_{10}-\mathrm{C}_{15}$ & 13.1(3) & -14.2 \\
\hline $\mathrm{C}_{3}-\mathrm{C}_{4}-\mathrm{C}_{5}-\mathrm{C}_{6}$ & $-61.5(2)$ & $\mathrm{C}_{11}-\mathrm{C}_{12}-\mathrm{C}_{13}-\mathrm{C}_{14}$ & $61.3(2)$ & -60.1 \\
\hline $\mathrm{C}_{2}-\mathrm{C}_{3}-\mathrm{C}_{4}-\mathrm{C}_{5}$ & $41.1(2)$ & $\mathrm{C}_{12}-\mathrm{C}_{13}-\mathrm{C}_{14}-\mathrm{C}_{15}$ & $-44.1(2)$ & 42.5 \\
\hline $\mathrm{C}_{4}-\mathrm{C}_{3}-\mathrm{C}_{2}-\mathrm{C}_{7}$ & $-11.6(3)$ & $\mathrm{C}_{10}-\mathrm{C}_{15}-\mathrm{C}_{14}-\mathrm{C}_{13}$ & $14.5(3)$ & -12.7 \\
\hline $\mathrm{C}_{4}-\mathrm{C}_{5}-\mathrm{C}_{6}-\mathrm{C}_{7}$ & $46.2(2)$ & $\mathrm{C}_{10}-\mathrm{C}_{11}-\mathrm{C}_{12}-\mathrm{C}_{13}$ & $-42.9(2)$ & 44.2 \\
\hline $\mathrm{C}_{1}-\mathrm{O}_{1}-\mathrm{C}_{8}-\mathrm{C}_{7}$ & $0.2(2)$ & $\mathrm{C}_{10}-\mathrm{C}_{9}-\mathrm{O}_{4}-\mathrm{C}_{16}$ & $2.9(2)$ & 0.05 \\
\hline
\end{tabular}


Table 8 Geometrical parameters $(\mathrm{d}, \theta$ and $\varphi$ ) of the intermolecular $\mathrm{C}=\mathrm{O} \ldots \mathrm{C}=\mathrm{O}$ interactions in 3,4,5,6-tetrahydrophthalic anhydride observed by X-Ray technique [4] and calculated using the Hopt- and FullOpt-models.

\begin{tabular}{|c|c|c|c|c|c|c|c|c|c|c|}
\hline \multirow[b]{2}{*}{$\mathrm{C}=\mathrm{O} \ldots \mathrm{C}=\mathrm{O}$} & \multirow[b]{2}{*}{ Type } & \multicolumn{3}{|c|}{$\mathrm{d}(\mathrm{O} \ldots \mathrm{C})[\AA]$} & \multicolumn{3}{|c|}{$\theta(\mathrm{O} \ldots \mathrm{CO})\left[^{\circ}\right]$} & \multicolumn{3}{|c|}{$\varphi(\mathrm{O} \ldots \mathrm{COC})\left[^{\circ}\right]$} \\
\hline & & $\begin{array}{l}\text { HOpt- } \\
\text { model }\end{array}$ & X-Ray[4] & $\begin{array}{l}\text { FullOpt- } \\
\text { model }\end{array}$ & $\begin{array}{c}\text { HOpt- } \\
\text { model }\end{array}$ & X-Ray[4] & $\begin{array}{l}\text { FullOpt } \\
\text {-model }\end{array}$ & $\begin{array}{c}\text { HOpt- } \\
\text { model }\end{array}$ & X-Ray[4] & $\begin{array}{l}\text { FullOpt } \\
\text {-model }\end{array}$ \\
\hline $\mathrm{C}_{1}=\mathrm{O}_{2} \ldots \mathrm{C}_{8}=\mathrm{O}_{3}$ & (I)-(I) & 3.001 & $2.957(2)$ & 2.997 & 90.2 & $89.0(1)$ & 89.5 & 92.7 & 91.8 & 93.7 \\
\hline $\mathrm{C}_{1}=\mathrm{O}_{2} \ldots \mathrm{C}_{8}=\mathrm{O}_{3}$ & (I)-(I) & 3.126 & $3.109(2)$ & 3.114 & 86.3 & $87.2(1)$ & 87.6 & 106 & 107.2 & 104.8 \\
\hline $\mathrm{C}_{8}=\mathrm{O}_{3} \ldots \mathrm{C}_{1}=\mathrm{O}_{2}$ & (I)-(I) & 3.144 & $3.148(2)$ & 3.120 & 87.3 & $88.8(1)$ & 86.2 & 71.9 & 71.0 & 70.7 \\
\hline $\mathrm{C}_{8}=\mathrm{O}_{3} \ldots \mathrm{C}_{1}=\mathrm{O}_{2}$ & (I)-(I) & 3.197 & $3.191(2)$ & 3.213 & 83.0 & $83.4(1)$ & 83.0 & 66.3 & 66.9 & 68.3 \\
\hline $\mathrm{C}_{16}=\mathrm{O}_{6} \ldots \mathrm{C}_{9}=\mathrm{O}_{5}$ & (II)-(II) & 2.989 & $2.926(2)$ & 2.998 & 88.9 & $89.5(1)$ & 84.4 & 78.5 & 100.2 & 80.9 \\
\hline $\mathrm{C}_{9}=\mathrm{O}_{5} \ldots \mathrm{C}_{16}=\mathrm{O}_{6}$ & (II)-(II) & 3.166 & $3.195(2)$ & 3.192 & 81.6 & $83.1(1)$ & 78.4 & 115.6 & 115.1 & 118.2 \\
\hline
\end{tabular}

Table 9 Density, space group, lattice energy (Elatt), zero point energy ( ZPE) and total vibrational contributions to free energy (Fvib) of the observed structure and the seven lowest hypothetical $Z^{\prime}=1$ structures of 3,4,5,6-tetrahydropthalic anhydride.

\begin{tabular}{|c|c|c|c|c|c|c|c|c|c|c|c|c|c|}
\hline structure & density & $\begin{array}{l}\text { Space } \\
\text { group }\end{array}$ & $\mathrm{a}$ & $\mathrm{b}$ & $\mathrm{c}$ & $\alpha$ & $\beta$ & $\gamma$ & Elatt & $\mathrm{ZPE}$ & $\begin{array}{c}\text { Elatt + } \\
\text { ZPE }\end{array}$ & $\begin{array}{l}\text { Fvib } \\
298 K\end{array}$ & $\begin{array}{c}\text { A } \\
298 \mathrm{~K} \\
\end{array}$ \\
\hline expt & 1.395 & $\begin{array}{l}P b c a, \\
Z^{\prime}=2\end{array}$ & 9.986 & 9.166 & 31.647 & 90 & 90 & 90 & -79.26 & 1.71 & -77.55 & -22.73 & -101.99 \\
\hline Pred 1 & 1.411 & $P b c a$ & 15.570 & 11.211 & 8.204 & 90 & 90 & 90 & -78.12 & 2.32 & -75.80 & -18.52 & -96.64 \\
\hline Pred 2 & 1.361 & $P b c a$ & 9.138 & 15.867 & 10.245 & 90 & 90 & 90 & -78.07 & 2.21 & -75.86 & -19.30 & -97.37 \\
\hline Pred 3 & 1.383 & $P b c a$ & 9.492 & 9.874 & 15.647 & 90 & 90 & 90 & -76.81 & 2.38 & -74.43 & -18.66 & -95.47 \\
\hline Pred 4 & 1.378 & Pbca & 11.662 & 8.069 & 15.840 & 90 & 90 & 90 & -75.83 & 2.21 & -73.62 & -19.40 & -95.23 \\
\hline Pred 5 & 1.356 & $P 2_{1} 2_{1} 2_{1}$ & 15.765 & 7.247 & 6.589 & 90 & 90 & 90 & -75.10 & 2.32 & -72.78 & -18.90 & -94.00 \\
\hline Pred 6 & 1.343 & $P 2_{1} / n$ & 6.776 & 13.236 & 8.245 & 90 & 94.07 & 90 & -74.97 & 2.21 & -72.76 & -19.62 & -94.59 \\
\hline
\end{tabular}




\begin{tabular}{|c|c|c|c|c|c|c|c|c|c|c|c|c|c|}
\hline Pred 7 & 1.370 & $P 2_{1} / a$ & 8.002 & 11.472 & 8.140 & 90 & 80.95 & 90 & -74.79 & 2.13 & -72.66 & -20.40 & -95.19 \\
\hline Pred 8 & 1.370 & $P 2_{1} 2_{1} 2_{1}$ & 7.584 & 14.432 & 7.010 & 90 & 90 & 90 & -74.54 & 2.15 & -72.39 & -20.09 & -94.63 \\
\hline Pred 9 & 1.317 & $P 2{ }_{1} / a$ & 7.791 & 8.607 & 11.056 & 90 & 88.36 & 90 & -74.51 & 2.21 & -72.30 & -19.87 & -94.38 \\
\hline Pred 10 & 1.354 & $P 2_{1}$ & 7.324 & 6.532 & 8.010 & 90 & 80.57 & 90 & -74.25 & 2.17 & -72.08 & -19.58 & -93.83 \\
\hline
\end{tabular}

